\title{
Lutherske kirker mellem dansk og tysk
}

\section{Omrids af Sønderjyllands kirkehistorie efter reformationen}

\author{
af LARS N. HENNINGSEN
}

Kirkehistorien er en afgørende vigtig del af Sønderjyllands historie. Emnet har været genstand for en del fremstillinger. Ofte er kirkens historie blevet betragtet under en nationalpolitisk synsvinkel. Artiklen her trækker lange linjer i kirkehistorien og ser på spørgsmålet om kirkens rolle mellem dansk og tysk, nord og syd. Samtidig stiller den kritiske spørgsmål: Hvor langt er det begrundet og forsvarligt at se kirken især som aktør i spillet mellem dansk eller tysk i grænselandet? Er en national problemstilling overhovedet dækkende for hele kirkehistorien?

Lige siden middelalderen har Sønderjylland - eller Slesvig - været et område, hvor dansk og tysk mødtes. Det gjaldt på det sproglige område, det gjaldt $i$ retsvæsen og forvaltning - og det gjaldt $i$ kirken.

Her blev reformationen et afgørende vendepunkt. Den medførte, at gamle bånd blev brudt. Hidtil havde Slesvig været del af den danske kirkeprovins med centrum i Lund. Med reformationen fik henholdsvis Danmark og Slesvig med Holsten hver sin kirkelige grundlov. For Danmark blev der i 1537 udstedt en kirkeordinans, på latin og med dansk oversættelse. På trods af alle hensigter kom den ikke til at gælde syd for Kongeåen. Her udstedtes tværtimod i 1542 en separat kirkeordinans, der var forfattet på latin og med plattysk oversættelse. Den gialdt for Slesvig og Holsten. Dermed blev de to hertugdømmer skilt fra den danske kirke. Resultatet var, at kirkeforholdene nord og syd for Kongeågrænsen $\mathrm{i}$ de følgende århundreder blev skarpt adskilte.

Slesvig og Holsten fik efter reformationen sin egen statskirke. Det blev en kirke præget af strømme både sydfra og nordfra. Slesvig blev front og bro mellem nord og syd. I nogle perioder var der mest tale om strømme fra syd mod nord - det var reglen. Til andre tider gik 
der påvirkninger fra Danmark til Slesvig - det var undtagelsen før 1920. Gennem århundreder voldte mødet ikke problemer, nationale momenter gjorde sig knap nok gældende ved siden af rent kirkelige og statslige synsmåder. Slesvig fik karakter af en bro mellem nord og syd. Det var først i 1800-årene, at der trods den fælles lutherske bekendelse blev tale om en dansk kristendom og en tysk kristendom. Sønderjylland blev nu til mødestedet mellem kirkesyn og kirkepraksis af henholdsvis dansk og tysk art. Slesvig blev en front. Det blev kendetegnende for århundredet efter 1830'erne. Kirkerne blev nærmest uforsonlighedens sidste bastion. Først i allernyeste tid har dansk og tysk fundet et mere harmonisk indbyrdes forhold $\mathrm{i}$ kirkeverdenen.

I det følgende vil vi se på linjerne i dette vekselfulde forløb - i en slags sønderjysk kirkehistorie en miniature.

Hvad ved vi om dette store emne? Der er skrevet meget om Sønderjyllands kirkehistorie. Men kendetegnende for næsten al litteraturen er, at den betragter emnet med nationale briller. Reformationen og dens mænd kom sydfra, fra en tysk verden og skulle virke $i$ et land, som i alt fald oprindelig var dansk. Derfor er kirken - især i danske fremstillinger - blevet beskyldt for at have været én af de fortyskende kræfter. Forfatterne har spurgt: Var kirken og dens mænd til en given tid danske - eller tyske? Virkede de for eller imod det danske sprog? Dette synspunkt præger et standardværk som Jørgen Larsen: Sønderjyllands Kirkehistorie (1946), hvor det f.eks. hedder: "Men i national henseende skulle reformationen desværre blive kostbar for danskheden i Sønderjylland. [...] vi må beklage den fortyskning, som fulgte $i$ dens spor. [...] Der viste sig en tilbøjelighed til at indføre tysk, hvor det overhovedet var muligt, selv om reformationen just som princip hævdede modersmålets ret. I stedet for Luthers »Hellige Modersmål« satte man »Luthers hellige Modersmål«.«1

At se på historien med sådanne briller er imidlertid forældet, eller rettere et udtryk for problemstillinger, som rådede fra 1830'erne og frem til 1950'erne, det vil sige i nationalismens periode. I dag må vi i stedet preve at betragte historien mere ud fra hver tids egne forudsætninger. Det dansk-tyske er ikke den rigtige problemstilling for hele historien. Der må snarere skelnes mellem »den gamle verden« og "den moderne verden".

Den gamle verden er tiden fra reformationen indtil det tidspunkt, hvor den moderne nationalisme og "folkelighed “ dukkede op, altså tiden ca. 1530-1830. I denne periode blev al kraft sat ind på sikre den 
$-4$

"Reformationen set $i$ oplysningstidsbelysning" - sådan kan man sammenfatte budskabet $i$ dette kobberstik $i$ bind 6 af den danske oversættelse af den fremtrædende Kiel-professor Wilhelm Ernst Christianis Slesvig-Holsten-historie fra 1796. Bindet behandler reformationstiden fra 1524 til 1588. Oprejst på alteret ses bibelen og korset. Gennem Luthers og Christian III's reformation var de blevet den evangelisk-lutherske kirkes rette fundament. Alt det overflødige fra pavetiden var derimod væltet omkuld eller ødelagt og dermed afvist. P\&̊ alteret ligger den valtede monstrans: Den katolske nadverforstdelse er afvist. I støvet nedenfor alteret ligger rosenkransen, rogelseskarret og den tredelte tiara eller pavekrone. Den sønderbrudte krumstav markerer, at det efter reformationen er slut med den misbrugte bispemagt. Over det hele stråler solen og fortrænger udydens og lasternes formorkende skyer. Solen - Gud, Evangeliet, oplysningen, det klare, naturlige, livgivende og sande lys - giver liv til både dyden og udødeligheden, sidstnæonte symboliseret af sommerfuglen, et billede pd den udødelige sjæl. Foto: Dansk Centralbibliotek for Sydslesvig.

såkaldt »rette tro«. Desuden var det kirkens opgave at tjene statens tarv.

Først i den moderne verden - efter 1830'erne med opkomsten af nationale, folkelige bevægelser og grundtvigianismen - blev problemstillingen en anden. Nu kom modsætningen mellem det kirkelige og det nationale på dagsordenen. Det gjaldt i særlig grad i et område som Sønderjylland, hvor dansk og tysk stødte sammen. I Sønderjylland blev situationen tilspidset og fik en helt speciel dimension under fremmedherredømmet fra 1864 til 1920. Denne fase varede langt op i 1900-årene.

I dag lever vi i efterslættet af denne nationalt prægede periode. Vi er på vej ind $i$ en ny tid, hvor kirken ikke mere er gidsel af det nationale, som den blev det fra 1830'erne.

Der er derfor behov for en fremstilling af kirkehistorien, som ikke mere gør det nationale til øverste problemstilling for alle perioder. I det følgende skal trækkes nogle lange linjer og forfølges nogle hoved- 
spørgsmål: Hvem prægede kirken gennem tiden - kom kirkens mænd fra nord eller syd? Hvilke bevægelser satte gennem tiden deres præg på kirken - kom de nordfra eller sydfra? Hvordan tacklede den lutherske kirke spørgsmålet om sproget? Hvordan var forholdet mellem kirken og det nationale? Var der tale om forskellige kirkesyn - et dansk og et tysk?

\section{Den gamle verden}

Udgangspunktet var 1542-kirkeordinansen for Slesvig og Holsten. Den blev som nævnt grundlov for den slesvigske kirke. Dermed blev Slesvig udskilt af kirkeprovinsen med centrum i Lund. ${ }^{2} \mathrm{Nu}$ var ikke ærkebiskoppen i Lund, men landsherren øverste leder af kirken. Syd for Kongeåen var der oprettet en statskirke; den lå indenfor det danske monarki, men var adskilt fra Kongeriget Danmarks kirke.

\section{Forvaltning og styre}

Den nye kirke var en fyrstekirke - landsherren var kirkens overhoved, summus episcopus. Det fremgår klart af de gejstliges embedsed. Bisperne, eller generalsuperintendenterne som de også blev kaldt, skulle føre tilsyn med Guds ords forkyndelse i henhold til de profetiske skrifter og den augsburgske konfession, eksaminere præstekandidater, føre opsyn med præster og provster, holde visitats, afskaffe misbrug og indberette sådanne til kongen. Også for præsterne var det embedspligt at være loyale statstjenere. De forkyndte ordet, publicerede kongens forordninger fra prædikestolen og skulle selvfølgelig aflægge ed til kongen og hver søndag i kirkebønnen ordrigt bede for landsherren og hele hans hus. ${ }^{3}$ Det blev taget alvorligt: Ved indlemmelsen af den gottorpske del af Slesvig i kronen i 1721 kom den eneste reelle tøven eller modstand mod statsændringen fra nogle gottorpske provster. De var loyale statstjenere og havde svare samvittighedskvaler ved pludselig at skulle gå ind under et nyt herskab. ${ }^{4}$

Gang på gang blev det kirkens opgave at bidrage til hyldest af den bestående stat og dens fundament. Hver gang en konge var død og en ny kom på tronen, blev der i alle kirker holdt minde- og takkegudstjenester for den afdøde, og Guds velsignelse blev nedbedt over efterfølgeren. I 1749 fejredes 300-året for den oldenborgske stammes tronbestigelse med festgudstjenester i hver eneste kirke. Foran de for- 
samlede menigheder takkede præsterne for, »at Gud gennem de fortræffelige konger af den oldenborgske familie har ladet tilflyde disse kongeriger og lande så mange velgerninger af åndelig og timelig art«. ${ }^{5}$ Noget lignende skete i 1760 ved 100 -året for enevældens indførelse. Kirken havde en meget vigtig opgave med at indpode befolkningen loyalitet over for kongen og staten som det gudgivne regimente. Det blev ikke anderledes, da Slesvig og Holsten efter 1864 fik nye landsherrer - nu i Berlin. Helt i stil med traditionen fra dansk tid blev der f.eks. i 1897 udsendt befaling fra den nye kirkemyndighed, Overkonsistoriet i Kiel, om markering af 100-års dagen for kong Wilhelm I's fødsel: Præsterne skulle minde om »den rige nåde Vorherre har skænket det tyske folk og den evangeliske kirke ved den afdøde kejsers regimente og indflydelsen af hans kristelige personlighed ${ }^{6}{ }^{6}$

Kirkens opgave var med andre ord at bidrage til at virkeliggøre den kristelige mission, som var pålagt kongen som Herrens salvede. Præsten og forfatteren Erik Pontoppidan udtrykte det kort og rammende i sin roman Menoza fra 1743, hvor han karakteriserede kong Christian VI på denne måde: "Vi har, Gud være lovet, en Herre, som gør sin hovedsag af at svare til sit navn og i alle sine lande at befordre kristendom eller rydde dens forhindringer af vejen. Den saliggørende sandhed er her ej alene ikke i tryk og foragt, men også i højagtelse. ${ }^{7}$

For kirken var spørgsmål om dansk eller tysk derfor i denne periode irrelevante. Kirken var en statsinstitution, som skulle sikre den rette tro og statens enhed under landsherren. Kirken skulle underbygge den rådende samfundsorden. Sådan var det $\mathrm{i}$ alle lutherske lande.

Kirkens folk - hoor kom de fra?

For reformationen var Wittenberg den hellige by, og i Danmark foregik kirkeomstillingen i tæt kontakt til Wittenberg. Johann Bugenhagen, som var professsor og præst i Wittenberg, var med til at give den nye danske kirke det rette lutherske fundament. I øvrigt blev den nye kirke mest båret af landets egne børn. De nye biskopper, Peder Palladius på Sjælland, Frands Vormundsen i Lund, Jørgen Jensen Sadolin på Fyn, Hans Tausen i Ribe, var landets egne børn. ${ }^{8}$

Det samme mønster møder man syd for Kongeåen, men her var islættet sydfra nok væsentlig mere markant. Reformatorerne i Haderslev fra 1528 og fremefter kom mest sydfra: Johann Wendt, som blev rektor for den vigtige præsteskole, var født i Goslar og kom 
fra et embede i Wittenberg, Den første provst i Haderslev, Eberhardt Weidensee, var født i Hildesheim og flyttede til Haderslev fra Magdeburg. Næsten i hele perioden fra 1542 til 1715 var alle sognepræster og provster i Haderslev sydfra, de fleste fra Luthers hjemland Sachsen. ${ }^{9}$

Noget lignende gælder de slesvigske biskopper. Den første i rækken var Tilemann v. Hussen, som beklædte embedet fra 1542 til 1551. Han kom fra Kleve i Rhinlandet, var blevet dr.theol. i Wittenberg 1537 og havde været rektor for universitetet i Kobenhavn 1539-41. Efter hans embedsperiode fik Slesvig helt frem til 1713 to forskellige rækker af biskopper, idet de to landsherrer - kongen og hertugen - indsatte hver deres kirkeledere. Frem til 1848 var rækken sammensat af 13 tyske, 4 fra Holsten, 4 fra Sydslesvig. Kun 1 eller 2 havde dansk modersmål, og alle kom selvfølgelig med tysk uddannelse..$^{10}$

Det store kontingent af tyskere ses klart, når man opregner rækken af kongelige biskopper: ${ }^{11}$

$\begin{array}{lll}\text { Stephan Klotz } & 1636-1668: & \text { fra Westfalen } \\ \text { Bonaventura v. Rehefeld } & 1668-1673 & \text { fra Sachsen } \\ \text { Johan Hudemann } & 1673-1678 & \text { fra Holsten } \\ \text { Christian von Stöcken } & 1678-1684 & \text { fra Rendsborg } \\ \text { Josua Schwartz } & 1684-1709 & \text { fra Pommern } \\ \text { Theodor Dassow } & 1709-1721 & \text { fra Hamborg } \\ \text { Thomas Clausen } & 1721-1724 & \text { fra Flensborg } \\ \text { Andr. Hoyer } & 1724-1728 & \text { fra Karlum } \\ \text { Joh. Georg Conradi } & 1728-1747 & \text { fra Riga } \\ \text { J.Fr. Reuss } & 1749-1757 & \text { fra Württemberg } \\ \text { Adam Struensee } & 1759-1791 & \text { fra Brandenburg } \\ \text { J.G.C. Adler } & 1792-1834 & \text { fra Arnæs } \\ \text { Chr. Fr. Callisen } & 1835-1848 & \text { fra Glückstadt }\end{array}$

Når det gælder præsterne, rekrutteredes mange i den første tid efter reformationen fra Thüringen, Hessen, Sachsen, Westfalen eller Rhinlandet. Hen i 1600-1700-tallet kom lokale folk mere og mere frem. Der opstod lokale præstedynastier; især i perioden 1750-1848 var mange præster af lokal bondeherkomst. Men i alle tilfælde fik præsterne deres uddannnelse ved tyske universiteter. Strømmen gik fra syd til nord. Det illustreres klart af status i 1848: Af Slesvig stifts i alt 237 præster havde da kun 29 ved fødsel eller uddannelse tilknytning til 
kongeriget, og folkene nordfra havde svært ved at gøre sig gældende syd for Kongeåen. Slesvigske teologer så skævt til kongerigsk fødte præster i Slesvig. De skønnedes »ikke passende for vore forhold," som det blev udtrykt. ${ }^{12}$

\section{Ortodoksiens periode}

I Danmark fik ortodoksien sin storhedstid under Christian IV. Det gjaldt om at sikre rettroenhed i stat og kirke. Alle skulle lære at tænke og tale ens om Gud og guddommelige ting. Til den ende blev der ført et benhårdt felttog for Luthers nadveropfattelse og mod calvinisternes vranglære. Det var den statskirkelige organisations blomstringstid, hvor folk og rige skulle gøres til én kristen menighed. Midlet var disciplineringsforanstaltninger og kirketugt for at sikre den rette lære. Kun derigennem kunne man forhindre, at Guds straf ramte landet. Fremtrædende kirkemænd som Sjællands biskop 1615-1638 Hans Poulsen Resen og hans efterfølger Jesper Brockmann førte an i denne politik og ivrede i skrift og tale mod calvinister og papister. En hel række forordninger blev gennemført for at sikre den rette kirkelige enhed og orden. I 1629 indførte en forordning om kirketugt nærmest et regulært tankepoliti, og kirkeværgerne fik stramme påbud om at føre opsyn med sognebørnenes vandel. I 1643 samlede en reces regler til styrkelse af det kirkelige embede og gennemførte kirketugt og ensretning. I 1685 kom en ny ritualbog for hele landet, i 1688 en alterbog. Dermed havde den tidlige enevælde nået at gennemføre en væsentlig grad af kirkelig ensartethed nord for Kongeåen. ${ }^{13}$ Helt sådan gik det ikke i Slesvig. Her lykkedes det aldrig at gennemføre en tilsvarende ensartethed, og der var forskelle mellem kongens og den gottorpske hertugs områder.

Det gottorpske område fik sit særpræg netop i ortodoksiens glansperiode, da der en kort tid blev åbnet for en calviniserende kirkepolitik. ${ }^{14}$ Årsagen var den personlige indstilling hos især hertug Johann Adolf (1590-1616). Fra sin opdragelse i Hessen nærede hertugen calvinistiske sympatier, og han blev påvirket af en tendens til tilnærmelse mellem luthersk og reformert kirke, som på den tid mærkedes i flere tyske stater. Ved hertugens hof rådede der en liberal ånd kendetegnet af åbenhed over for træk fra flere af de reformatoriske retninger. Resultatet viste sig i en ny præsteed for gottorpske præster, som svækkede den ellers gængse front mod åbenlys eller fordækt calvinisme. 
Det blev forbudt at rase mod calvinisterne fra prædikestolene, den gammellutherske biskop Jacob Fabricius den Ældre blev afskediget 1610, og i stedet blev indsat et kirkeråd. Som biskop blev indsat en calvinist fra Hessen ved navn Philip Cæsar.

Dog blev de calvinistiske træk især et fænomen ved hoffet. Uden for hofkirken nåede reformerte ceremonier ikke, og i befolkningen var der væsentlig modstand mod at forlade den nedarvede kirkeordning. Folk ville holde fast ved den augsburgske konfession. Folket blev da heller ikke tvunget til et konfessionssskifte svarende til landsherrens. Ved hertugens død i 1616 genoprettedes tingenes tidligere tilstand. Den tidligere biskop Jacob Fabricius den Fldre blev genindsat som luthersk biskop, og det lutherske kirkeregimente fortsatte. En streng ortodoksi som i Danmark kom dog ikke på tale i Gottorp. Også under den følgende hertug, Friedrich III, rådede en vis liberal religiøs tolerance - påvirket sydfra, og ved det nystartede Kiels Universitet var der plads til synkretisme og mådehold. Alt dette gør kirkehistorien i det gottorpske hertugdømme til et særtilfælde, forskelligt fra forholdene $i$ kongeriget.

I den kongelig del derimod blev ortodoksien sat i højsædet. En række markante biskopper i perioden 1636-1724 stod for en strengt luthersk rettroenhed, således som den kendtes i Danmark. Et af midlerne blev i årene 1646-1724 afholdelse af synoder.

Særlig typisk for denne periode var biskoppen i årene 1636-1668 Stephan Klotz. Han stammede fra Westfalen og havde $\mathrm{i}$ årene forud været professor i Rostock. I den danske konges tjeneste blev han en energisk statskirkemand, som under indtryk af krigens ulykker gik til kamp for den rette lære og kirkedisciplin ud fra opfattelsen, at vejen frem gik gennem tvangsforholdsregler og kirketugt. De bevarede visitatsberetninger vidner om et utrætteligt arbejde for at optugte sognefolkene til gudsfrygt og gode sæder og at opdrage alle efter Luthers katekismus. Derfor tog han skridt til at indføre konfirmationen, og han tog særlige kirkesynoder i brug som middel til at hævde kirkedisciplinen. ${ }^{15}$

Konkret viste denne tankegang sig i en række forordninger, som meget lignede de tilsvarende fra kongeriget. I 1636 kom en politiforordning til indskærpelse af moral og gudsfrygt, i 1641 bestemmelser om offentlig kirkebod, i 1646 forordning mod præsters drikfældighed. ${ }^{16}$

Det effektive og regelrette kirkestyre påkaldte sig stor anerkendelse 


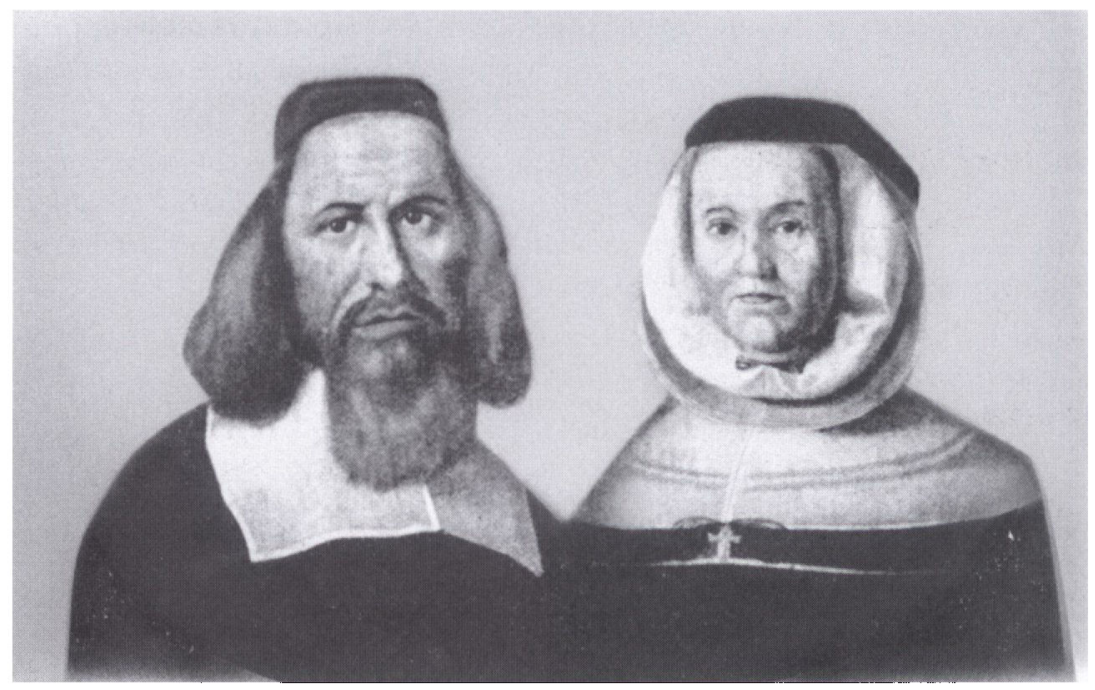

Stephan Klotz (1606-1668) og hustru Catharina fodt Runge. Dobbeltportræt pa Klotz' epitafium i St. Nikolai kirke i Flensborg. Klotz blev den måske mest betydningsfulde kirkemand $i$ hertugdømmerne $i$ ortodoksiens periode. Han var uddannet ved universiteterne i Marburg og Rostock. Som kun 29-årig var han avanceret til præst, $d r$. theol., professor og universitetsrektor $i$ Rostock. I 1636 blev han udnæont til kirkeleder for den kongelige dele af hertugdommerne. Det blev hans opgave at sikre en ensartet og stærk styring af kirkens forvaltning og forkyndelse. Med sæde $i$ Flensborg loste Klotz sine opgaver som den ortodokse statskirkes embedsmand til Christian IV's storste tilfredshed. Sonnen, den senere kong Frederik III, lærte at sætte pris på Klotz. Efter tronbestigelsen kaldte han $i 1667$ Klotz til Kobenhavn som hofpræst og kongelig kirkerådgiver. Klotz dode allerede 1668, inden han nåde at tage fat på de nye opgaver. Foto: Arkivet ved Dansk Centralbibliotek for Sydslesvig.

hos kong Frederik III i København. I 1667 blev Klotz kaldt til København for ved siden af embedet som biskop at varetage en fremtræedende stilling som kongens rådgiver og tysk hofpræst. Men i dansk-sønderjysk historieskrivning har han ellers fået et slet eftermæle. Det skyldes initiativer på det sproglige område. I 1661 påtvang han det dansktalende Hanved Sogn umiddelbart vest for Flensborg en tysk præst fra Rostock, hvor Klotz før havde virket, og også St. Vi Sogn sydvest for Flensborg fik en tysktalende præst fra Rostock. Det førte til protester fra sognene - men Klotz fik sin vilje. ${ }^{17}$ Sådanne tiltag har i eftertiden placeret Klotz blandt de medskyldige til Sønderjyllands gradvise fortyskning. For datidens kirkefolk så sagen imidlertid helt anderledes ud. For dem drejede det sig om at sikre orden og rettroenhed $i$ kirken. Og her var en god præst fra Luthers land det rette mid- 
del. Ved at give plads for det af Luther skabte højtyske sprog blev det muligt at sikre sig mod fejltolkninger af Luthers bibeloversættelser, katekismer og andre skrifter. Nationale tankegange lå ikke for disse tiders kirkemænd. De havde rent teologiske intentioner, ikke tanke for folkesproget. Dette blev først interessant for den følgende generations pietister.

Blandt biskopperne blev Josua Schwartz fra 1684 til 1709 den sidste repræsentant for den rene ortodoksi. De reformerte og den frembrydende pietisme blev bekæmpet, og der fremkom anklager mod præster, som forsyndede sig mod den rette lære. ${ }^{18}$

\section{Pietismen}

Fra 1720 'erne blev tonen en anden. Præst efter præst vendte hjem fra uddannelse ved universiteter, hvor der nu fra lærestolene udbredtes en ny kirkelig retning: pietismen.

Wittenberg var ikke længere det førende lærested, men teologerne søgte mod Halle og Jena. Vækkelse, omvendelse, fromhed, praktisk kristenliv og konkrete initiativer for bedre skoler og fattigforsorg blev centrale punkter for unge teologer. De nye tanker kunne udplantes gennem bibelkredse, hvor lægfolk studerede skriften til opbyggelse og dygtiggørelse og derved nåede frem til troens vished gennem personlig erfaring. I forhold til tiden forud var der tale om en tendens i retning af subjektivisme. Afgørende var den personlige inderlighed $i$ tilegnelsen af troen. Det personlige gudsforhold fik en ny betydning og førte naturligt til øget interesse for folkesproget. Kun når der var overensstemmelse mellem modersmål og kirkens forkyndelse, kunne budskabet om Frelseren få fri indgang hos den enkelte. I hertugdømmerne blev de nye tanker repræsenteret af de tre biskopper Joh. Georg Conradi (1728-47), J.Fr. Reuss (1749-57) og Adam Struensee (1759-91). ${ }^{19}$

Bevægelsen kom sydfra, og det er tydeligt, at Slesvig i disse år blev en bro nordpå for de nye tanker. En hel kreds af teologer fra Slesvig var $\mathrm{i}$ disse år med til at udplante pietismens holdninger, først $\mathrm{i}$ deres virkekredse syd for Kongeåen og derefter i kongeriget, hvor flere fik indflydelsesrige stillinger, i nogle tilfælde med nær kontakt til hoffet og den enevældige konge, Christian VI. Til denne kreds hørte Joh. Bartholomæus Bluhme, fra Tønder (1681-1753). Han begyndte som præst i Borne, og kom så til København som tysk hofprædikant 
i 1729. Derfra blev der åbnet vej til stilling som kongelig konfessionarius og medlem af generalkirkeinspektionskollegiet. ${ }^{20}$ En anden var Enevold Ewald, præstesøn fra Højst. Som ung teolog arbejdede han for pietismens udbredelse i Vestslesvig, kom så til Kobenhavn, hvor han blev forstander for Vajsenhuset og blev hvad man i dag ville kalde pietistisk "modepræst«. Han var med til at forberede konfirmationens indførelse i Danmark. Mest kendt er nok brødrene fra Randerup, hvor H. A. Brorson endte som biskop i Ribe og Broder Brorson overtog bispestolen i Ålborg $1737-78 .{ }^{21}$ En anden sønderjyde af samme holdning var Peder Hygom fra Hygum, som efter nogle år som præst i Lintrup-Hygum indtog bispestolen i Århus 1738-64. Særlig alsidig var Erik Pontoppidan (1698-1764), der begyndte som præst i Nordborg og Havnbjerg, og via embedet som hofprædikant i Kobenhavn nåede ikke blot en professortitel og bispestolen i Bergen, men også blev dr. theol. og prokansler for Kobenhavns Universitet. Et tydeligt udtryk for denne tids reformønsker var i Slesvig det kongelige reskript af 1761 til forbedring af skolevæsenet. Ungdommen skulle bibringes den undervisning, der skulle gøre dem til kristne og mennesker. Kristendommen stod på førstepladsen.

\section{Oplysningstiden}

I pietismens periode blev Sønderjylland således en vigtig bro for nye kirkelige tanker sydfra, og slesvigske gejstlige var med til at forme kirkepolitikken i kongeriget. Også i den efterfølgende tid - oplysningstiden - kom der impulser sydfra. Det var påvirkninger af almen europæisk karakter. Dogmatikken skulle renses for gammel »overtro", der blev prædiket populær filosofi med moralitet som væsentlig bestanddel. Jesu lære blev forkyndt som morallære. Mennesket var af naturen godt. Ved oplysning var det muligt at nå til udødelighed og evig lyksalighed. ${ }^{22}$

Disse tanker i rationalismens fornuftsreligion fandt tilhængere i hertugdømmerne, endog mere udpræget end i kongeriget. I Danmark gik kirken ikke så langt som i Slesvig. Den danske kirkes forstemand i perioden 1783-1808, Sjællands biskop Balle, stod fast på meget af det nedarvede på en tid, hvor de mere moderigtige ånder krævede reformer i gudstjeneste og børnelærdom. Overfor f.eks. hofpræst og kgl. konfessionarius i Kobenhavn Christian Bastholms forslag 1785 til ny liturgi i tidens smag stod Balle afvisende, og heller ikke Balles Evange- 
lisk-kristelig Salmebog var så yderliggående i sine ændringer, som tiden ellers kunne lægge op til. ${ }^{23}$

I Slesvig derimod gik man videre. Ved Kiels Universitet virkede den tidligere hofpræst i København Johann Andreas Cramer som professor $\mathrm{i}$ årene 1774-1788 og fremmede her de nye tanker. Han udgav i 1785 en ny katekismus, hvor vægten lå på det moralske indhold. Den fandt vid udbredelse og kom også i en dansk udgave. Cramers Allgemeines Gesangbuch 1781 slog igennem overalt i de tysksprogede menigheder i hertugdømmerne. Den rummede 914 salmer, heraf 255 sange af Cramer selv. ${ }^{24}$ Et lærerseminarium i Kiel blev oprettet 1781 for at bidrage til folkeskolens forbedring - et hovedanliggende for oplysningstidens folk.

Den ivrigste aktør for de nye tanker blev Jacob Georg Christian Adler, der virkede som biskop i årene 1792-1834. En særlig indsats øvede han på skolefronten, hvor han tog initiativet til nye lokale skoleregulativer og den almene skoleforordning for Slesvig og Holsten $i$ 1814. På det rent kirkelige område ønskede Adler en reform af gudstjenesten i mere moderne eller forstandsmæssig retning. Ritualerne skulle forbedres og gudstjenesten formes efter en ny gudstjenesteordning, en såkaldt »agende«. Den gamle ordning, som byggede på Adam Olearius' Kirchenbuch fra 1665, var forældet og gået af brug, så der var opstået stor forskel fra sogn til sogn. Derfor tog Adler initiativ til en ny agende i 1797. Nu skulle fornuftens klare lys skinne gennem kirken. Prædiken blev defineret som et "offentligt læreforedrag", djævelen måtte ikke nævnes, nadveren blev nedprioriteret, salmesang indskrænket, fadervor fik en ændret form, og barnedåb blev henlagt til hjemmene. Så kraftige ændringer stødte dog an mod konservatismen i menighederne. I sogn efter sogn kom det til protester, der var så kraftige, at regeringen til slut valgte at overlade beslutningen om agendens indførelse til menighedens egen beslutning. Reformønskerne var altså gået for vidt - og noget tilsvarende blev heller ikke forsøgt $i$ kongeriget. ${ }^{25}$

\section{Kirken og sproget}

I de almindelige fremstillinger af kirkehistorien er der som nævnt viet det sproglige aspekt megen opmærksomhed. Det er fremhævet, at tysk sprog bredte sig i de slesvigske kirker efter reformationen. I virkeligheden skete der i sproglig henseende nok ikke de helt store æn- 
dringer netop som følge af reformationen - udviklingen fortsatte blot, som den længe havde været $i$ gang. Allerede før reformationen var kirken blevet dobbeltsproget, med dansk forkyndelse på landet i det nordlige Slesvig og plattysk i byerne og i de sydligere dele. Reformationen brød ikke med dette mønster. I 1528 blev dansk forudsat som landsbypræsternes kirkesprog i Haderslev-ordningen. Om søndagen skulle præsterne synge litaniet med hele folket på dansk, dåben skulle foregå på dansk, og området med dansk kirkesprog blev udvidet.

Alligevel betød reformationen nok på langt sigt et skridt $i$ retning af det tyske. Den nye lære kom sydfra med tyske hjælpere. Fra slutningen af 1500-årene synes grænsen mellem dansk og tysk kirkesprog at være lagt dér, hvor den stort set ligger den dag i dag - næsten svarende til landegrænsen af 1920. Skillelinjen gik nord for Flensborg fjord, nord om Bov, syd om Tønder-Højer. ${ }^{26}$ Der var således dansk kirke- og skolesprog i Nordslesvig - i købstæderne dog tysk skolesprog og blandet kirkesprog med tyske højmesser og danske fromesser. Det udtrykkes f.eks. således i en beretning fra 1758: "Den danske gudstjeneste i Flensborg og i de nordslesvigske købstæder holdes for de mange danskeres skyld, som især findes blandt tjenestefolkene." Eksempelvis var der i Haderslev by først i 1700 -tallet ugentlig to tyske og fem danske gudstjenester, og salmesangen var tysk også ved danske gudstjenester. Generelt var alter- og salmebøger længe kun på tysk, og i købstæderne i Nordslesvig var der tysk salmesang, også ved danske gudstjenester helt til $1800 .{ }^{27}$ Hvad angår det tyske kirkesprog havde det plattyske udspillet sin rolle omkring 1660 . Herefter dominerede det højtyske. I Aabenraa by blev plattysk f.eks. afløst af højtysk netop i årene omkring 1660. I 1691 udkom et kongeligt påbud, at alle hidtil latinske dele af gudstjenesten herefter skulle foregå på højtysk. ${ }^{28}$

Ikke desto mindre er det værd at bemærke, at dansk på lokalt plan i Nordslesvig bevarede en sikker plads i kirken. I retsvæesen og forvaltningens højere led blev sproget derimod efterhånden næsten ublandet tysk, også i de dansktalende områder. Tysk kirkesprog overfor dansk folkesprog var kun virkeligheden i Sydslesvigs landsogne. Gang på gang gav uoverensstemmelsen mellem folkesproget og kirkesproget her anledning til overvejelser. Flere biskopper og andre af kirkens egne mænd var opmærksomme på problemet. F.eks. foreslog biskop Jeremias Friedr. Reuss i 1757 i en afskedsbetænkning til Tyske Kancellis chef J.H.E. Bernstorff, at biskopembedet burde deles i to, et 

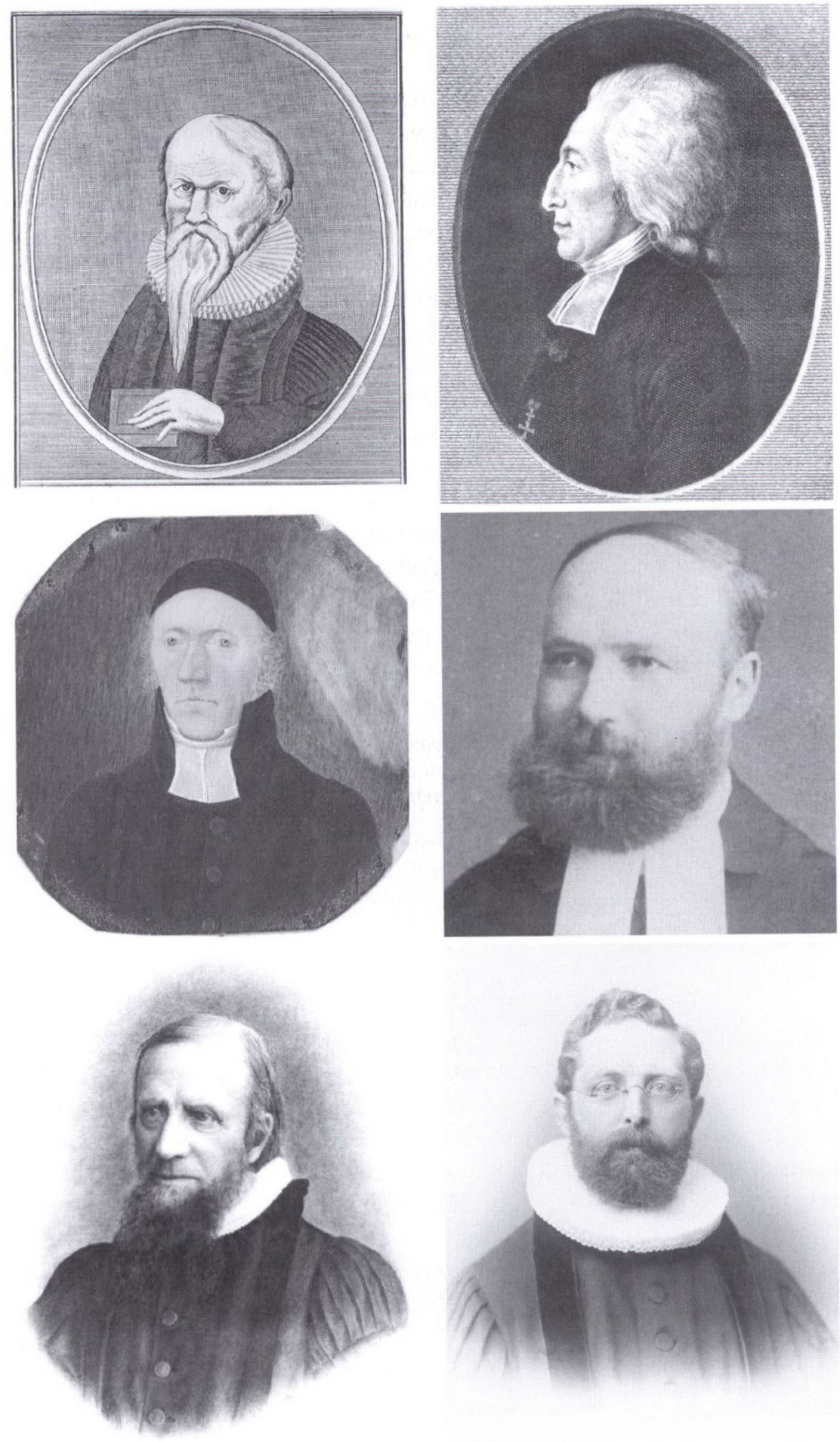
for Slesvig og et for Holsten, for dansk var en uundværlig egenskab for den slesvigske tilsynsmand. ${ }^{29}$ I oplysningstiden kunne flere præster se det »ufornuftige« $i$, at der var tysk kirke- og skolesprog i dansktalende sogne. I 1754 udtalte pastor Nissen i Uge: "Selvom vi er danske, foragtes vort modersmål sådan, at kirkesproget næppe $\mathrm{i}$ halvdelen af Tønder amt er dansk." Eller det lød fra Aventoft 1796: "Det er en tåbelig ordning, at skønt ingen i menigheden taler eller forstår tysk, skal præsten dog prædike hver søndag på tysk. « ${ }^{30}$

På regeringsplan var der dog ikke megen forståelse for sådanne klageråb. I 1661 blev menigheden i Hanved afvist, da den protesterede mod ansættelsen af en præst med utilstrækkelige danskkundskaber, som biskop Klotz havde påtvunget sognet. Et bevidst ønske om at skade dansk stod dog ikke på Klotz' dagsorden. I Eskris i Sydangel foretrak han en præst fortrolig med dansk på grund af folkesproget $i$ sognet. ${ }^{31}$ I flere tilfælde kvalte Tyske Kancelli dog anbefalinger til fremme af det danske sprog. I 1735 udstedte herskabet på Glücksborg en forordning om at indføre tyske gudstjenester hver 3. søndag i lyksborgske sogne på Sundeved. Menighederne protesterede, men kon-

Præstedragten har ændret sig gennem århundrederne. Efter reformationen blev datidens almindelige borgerlige dragt blandt gode borgerfolk og lærde, den fodlange kappe med pibekrave, lidt efter lidt fastlagt som det almindelige præsteornat. Pibekraven blev præsternes almindelige krave $i$ Danmark og $i$ hertugdommerne indtil langt op $i$ 1700-årene. Ogsa $i$ dele af Tyskland var den benyttet. I dele af det protestantiske Tyskland benyttedes dog ogsa fra 1600-årene og fremefter en krave med to flipper, de säkaldte "mosetavler". I Danmark og Slesvig og Holsten blev "mosetavlerne" meget populære hos præsterne i tiden ca. 1770-1830, hvorefter pibekraven igen fik overtaget. Kun $i$ Tyskland forblev "mosetavlerne" det almindelige og blev fra 1800-årene enerådende $i$ Preussen. "Mosetavlerne " blev derfor også bäret af hovedparten af landskirkens præster $i$ Sønderjylland fra 1864 til 1920, og benyttes stadig almindeligt $i$ de protestantiske kirker $i$ Tyskland. Kun i nogle af de gamle hansestæder, Lübeck, Hamborg, Lüneborg m.fl., benyttes endnu pibekrave. I 1920 kom pibekraven igen til Sonderjylland. Derfor er "mosetavlerne« $i$ Danmark blevet tolket som noget typisk tysk, $i$ modsxtning til den "danske" pibekrave. Sådan kan forskellen dog ikke beskrives. Ogsa $i$ »tysk tid « bar enkelte tyske præster pibekrave, og mange danske præster bar "mosetavler « $i$ årtierne på begge sider af år 1800. Et vue over en række præsteportrætter viser virkelighedens mangfoldighed. Øverst til venstre ses den gottorpske generalsuperintendent Jacob Fabricius den zldre, død 1640, med pibekrave, hvilket var det almindelige frem til $1770^{\prime}$ erne. Derefter folger til højre generalsuperintendent J.G.C. Adler, død 1834 og i den anden række t.h. sognepræst Peter Kier $i$ Østerløgum, død 1834, begge med »mosetavler", som var almindelige pd den tid. I midten til hojre bærer pastor Hans Tonnesen i Aabenraa/Hoptrup, død 1935, "tysk" krave. Saddan var kraven for hovedparten af landskirkepræsterne fra 1864-1920. Men der var undtagelser. Nederst ses to afgjort tysksindede præster. Begge bærer de »dansk " pibekrave, til venstre provst Gottig i Aabenraa, død 1904, og til højre Karl Niese i Flensborg, d. 1924. Fotos: Arkivet ved Dansk Centralbibliotek for Sydslesvig. 
gen stadfæstede i 1740 forordningen. ${ }^{32}$ Dette havde formelt-praktiske grunde, og forvaltningen kunne ofte også påberåbe sig folkets egen stemme. I Tønder udtalte pastor Prahl således omkring 1800, at folk ville modsætte sig forandring til dansk - sthi som de dårer de er, anser de en tysk prædiken for bedre og mere hellig end en dansk «. ${ }^{33}$

Et karakteristisk eksempel på problemstillingen var Adam Struensees holdning. Han var biskop i årene 1759-1791 og virkede energisk for at forbedre skolevæsenet og læreruddannelsen. Han lærte sig også dansk og kunne se, at der forelå et misforhold, såfremt der ikke var overensstemmelse mellem folkesprog og kirkesprog. Ved sin tiltræden anbefalede han for Angel, at gudstjenesten blev holdt i et for indbyggerne kendt sprog. Men generelt så han på sagen med bureaukraternes øjne. Der var behov for ensartethed. Overensstemmelse mellem skolesprog og kirkesprog var det ideelle. Hvor kirkesproget var tysk, måtte skolesproget også være det, uden hensyn til folkesproget, ellers blev præstens arbejde med ungdommens opdragelse i de kristne børnelærdomme vanskeliggiort. Der burde derfor indføres tysk skolegang for at sikre overensstemmelse med prædikesproget, hvor dette var tysk - det vil sige i hele Sydslesvig, altså også hvor folkesproget var dansk. Når skolesproget blev udelt tysk og læreren holdt op at bruge dansk, selv hvor folkesproget var dansk, ville man opnå, at eleverne fik bedre udbytte af den tyske konfirmandforberedelse og den tyske gudstjeneste, alt til gavn for oplæringen af folket i den rette kristentro. Menighederne skulle med andre ord indrette sig efter præsterne - ikke omvendt. Resultatet blev i 1768 et cirkulære til provsterne i Sydslesvig: tysk katekismusundervisning skulle indføres overalt, for på den måde at lette tilegnelsen af tysk konfirmandundervisning og tysk gudstjeneste. ${ }^{34}$

\section{Den moderne verden}

Fra begyndelsen af 1800-årene, og i forstærket grad fra 1830'erne, trængte nye tanker om folk og stat sig frem. I løbet af århundredet kom de til at betyde en revolution af den gammelkendte verden. Kirken blev trukket ind i en folkelig-national kamp, den blev kampplads mellem nord og syd. Hvor kirken i grænselandet hidtil havde været en næsten selvfølgelig bro for kirkelige strømninger sydfra, blev der nu tale om forskelle mellem kirken i Danmark og kirken i Tyskland. Kirken blev mere front end bro. 
Flere udviklingslinjer gav baggrund for, at nye modsætninger voksede frem.

For det første fremkom der nye synspunkter om modersmålets betydning. Hidtil var forholdet mellem folkets sprog og kirkens forkyndelse mest blevet set under en praktisk synsvinkel. Det gjaldt om at sikre, at folket tilegnede sig kirkens sandhed og budskab. Til den ende kunne det evt. komme på tale at vise hensyn til folkets sprog. $\mathrm{Nu}$ bredte sig den opfattelse, at sproget har en langt mere indgribende betydning - sproget er den faktor, hvorefter alt det øvrige må forme sig. I 1810 udstedte kongen et reskript, som gav forvarsel om, at fremtiden ville tillægge sproget ændret betydning. Hvor dansk var folkesprog, ønskede kongen, at tysk kirke-, skole- og administrationssprog skulle ophøre. ${ }^{35}$ Det var et voldsomt indgreb i bestående forhold. De fleste provster var tyskuddannede, og de frarådede. I kancelliet gav et af medlemmerne, den senere regeringspræsident J.O. Fr. Spies, udtryk for forståelse af den nye moderne opfattelse: "Et folks dannelse sammenhænger på den inderligste måde med sproget. [...] Selv de højeste tanker, de religiøse som de sædelige, opfattes og tilegnes kun af folket i dets oprindelige sprog. [...] Hvis man påtvinger folket et fremmed sprog, bliver deres regelmæssige vækst afbrudt og den helligste arv fra forfædrene går tabt for efterkommerne. ${ }^{36}$ I kancelliet var en sådan vurdering dog nærmest revolutionær. Spies' kolleger hældede mest til at se sagen fra statsligt-administrative, ikke kulturelle synspunkter. Sprogreskriptet blev henlagt. De følgende årtier viste imidlertid, at sådanne tanker havde fremtiden for sig.

For det andet blev tiden fra omkring 1817 kendetegnet af fremvæksten af kirkelige vækkelser. Der skete et opbrud i de hævdvundne kirkeretninger. Det gjaldt både Tyskland og Danmark. Tyskland oplevede en kristelig vækkelse, en patriotisk og moralsk rejsning og genfødelse af det tyske folk. En af banebryderne var den tyske evangeliske teolog Friedrich Schleiermacher (1768-1834) i Berlin. I 1799 havde han udsendt sine berømte Reden über die Religion. Han var derved med til at forberede Tysklands genrejsning. I 1806 havde han udtalt det fængende opråb mod Napoleon: "Deutschland ist immer noch da«.Ved sådanne tiltag blev han den første politiske prædikant i stor stil. Han forkyndte Tysklands kald som protestantismens værner. Det var ethvert folks opgave at virkeliggøre sin side af det menneskelige for at bidrage sit til, at menneskeheden kan blive et sandt afbillede af guddommen. Kristendommen er derfor fædrelandskærlighed, kirken 
må være national og forlange af sine medlemmer, at de føler sig som led i det nationale fællesskab. ${ }^{37}$

Til Slesvig og Holsten kom disse tanker bl.a. gennem Kiel-præsten Claus Harms (1778-1855). Harms var født i Sydditmarsken. Fra 1816 var han præst og provst $\mathrm{i}$ Kiel. Allerede i studietiden blev han vakt af Schleiermachers Reden über die Religion. Hjemme i Holsten var Schleiermachers program med til at fremkalde et initiativ, som gjorde Harms til en betydningsfuld kraft i den hjemlige kirke. I 1817 udsendte han en række teser, som blev skelsættende. Til Luthers 95 teser frjede han 95 egne. Ud fra et ortodoks standpunkt kaldte han til opgør med oplysningstiden. Han vendte sig mod den rådende rationalisme og liberalisme. Der var brug for en tilbagevenden til Luther, til religiøs vækkelse byggende på folkeligt liv og folkesproget. I Harms' univers var folkesproget det plattyske.

Tanker og bevægelser af den art gik over hele Tyskland i disse år. Det må dog tilføjes, at Harms ikke brød med de bestående statsforhold i hertugdømmerne. Han var tilhænger af enevælden. Kongen var salvet af Gud til sit kald, og kirken skulle også efter vækkelse af en ny ånd forblive i det gammelkendte forhold til staten, den danske konge. ${ }^{38}$

I hertugdømmerne fik de Schleiermacher-inspirerede holdninger stor betydning i den følgende tid. Nogle teologer stiftede bekendtskab med dem i studietiden, og efter nogle år sad der præster opdraget $i$ Schleiermacher-Harms-ånden i mange af embederne i Slesvig. I 1848 havde 10 slesvigske præster studeret under Schleiermacher, hans prædikener var trykt og kendt. Disse præster var tyske af dannelse. De var præget af drømmen om genrejsning af den tyske nation. De følte sig knyttet til tysk kirkeliv, de fandt det naturligt, at Slesvig som del af Slesvig-Holstens landskirke måtte blive en del af en samlet tysk nationalkirke. Schleiermachers appel til tysk patriotisme førte til, at den slesvigske gejstlighed sluttede aktivt op bag den slesvig-holstenske bevægelse. Præsterne sympatiserede med slesvig-holstenismen, og da man nåede frem til 1848, støttede de oprøret. ${ }^{39}$

Genfødelsen af tysk kirkeliv kom ikke til at stå alene. Også Danmark oplevede et nybrud inden for kirken. Beslægtede tanker satte sig snart spor i Danmark, og her er Grundtvig den centrale skikkelse. I 1810 havde Grundtvig indledt sit opgør mod rationalismen. Han udsendte sin såkaldte "dimisprædiken " med den fængende titel: "Hvi er Herrens ord forsvundet af hans hus? « Her fordømte han for- 
nuftsreligionen, kaldte til forståelse for modersmålets betydning og påpegede, hvordan der måtte være en livgivende forbindelse mellem kristendom og danskhed. Næsten fyndordsagtigt gav han udtryk for, at tonen $i$ kirken i Danmark måtte være anderledes end $i$ andre lande. I 1816 udtrykte han det i disse linjer i tidsskriftet Dannevirke: "Klokken i den danske Kirke/Det er Sagas klingre Skjold.«

Et sådant forhold mellem folket og kirken måtte få følger. I 1819 udtalte Grundtvig forudanende: „Spørger man, om jeg mener, strid kan undgås, da må jeg svare nej. « $^{40}$ Kirken måtte afspejle folkets sprog og ånd. Det var alene modersmålet i mund og bog, som kunne vække et folk. Førend kristendommen kunne blive rigtig forstået af et folk, måtte dets forkyndere have folkets modersmål fuldkommen $i$ deres magt. Derfor måtte Slesvigs danske menigheder også have præster, der kunne prædike på dansk. Det kunne ikke ske ved, at en tysk præst oversatte sin prædiken til dansk og lærte den udenad. Ordet måtte lyde i det sprog, som præsten brugte i sin tanke, sin tale og sin bøn. "Det følger nemlig af sig selv, at da kristendommen altid vil tale til hjertet, og intet sprog går os til hjerte som vort eget modersmål, så må kristendommen, for at nå sin hensigt, forkyndes på modersmålet. «1 $^{41}$ Det menneskelige var jordbunden, hvori det evige liv måtte plantes ind ovenfra gennem evangeliet. Men naturligvis måtte planten også tage form af den jord, hvor den skulle udfolde sig og virke. Derfor måtte kræves en dansk kristendom. Vel er Jesus den samme til evig tid, men det kristenliv, den kristendom han skaber, den er forskellig efter den folkeejendommelighed, der foreligger. ${ }^{42}$

Disse tanker var på mange måder i slægt med den kirkelige vækkelsesbevægelse i Tyskland. I Danmark blev de udbygget med Grundtvigs tanker om frihed i kirken. Disse kom også frem, da sprogreskripterne i Sydslesvig kom til drøftelse omkring 1860 . Her blev f.eks. fra dansk side anført, at en vej ud af problemerne kunne være at ansætte en dansk præst $i$ hvertandet sogn og en tysk præst $i$ hvertandet sogn. Det skulle så være muligt at løse sognebånd og at benytte udensogns præster. ${ }^{43}$ Sådanne grundtvigske tanker kom til Slesvig med pastor C.C. Boisen i Vonsbæk fra $1844-48$ og af N.L. Feilberg i Ullerup 1847. ${ }^{44}$ Det grundtvigske frihedsbegreb og Grundtvigs syn på kirkelig orden skurrede dog i ørerne hos de fleste præster i Slesvig. Tonerne nordfra kunne mest af alt give næring til slesvigske præsters ønske om at holde Slesvig fri af indflydelse fra den danske kirke.

Fremvæksten af de nye kirkestrømninger $\mathrm{i}$ henholdsvis Tyskland 
og Danmark betød, at kirken blev et stridsfelt mellem dansk og tysk. Der var nu tale om en kirkelig bevægelse nordfra, som også nåede frem til landet syd for Kongeåen. Men det var kun en svag strøm. Generelt var der frem til 1848 kun svag påvirkning nordfra. De afgørende strømme kom fortsat sydfra. I det kirkelige tidsskrift Kirchenund Schulblatt, som var ordførende og kendt i de fleste præstegårde, blev der næsten ikke bragt oplysninger fra Danmark. Øjnene var rettet mod syd. I 1846 hed det f.eks.: "Vor landskirke er en del af den evangeliske kirke, eller nærmere af Tysklands evangeliske kirke. « ${ }^{45}$

Alt dette, præsteflertallets påvirkning af en stærk kirkelig-nationalfolkelig vækkelse sydfra og den kun svage strøm af beslægtede, modsatrettede luftninger nordfra, gjorde, at der var lagt op til strid i kirkelige kredse. En stigende national modsætning anedes i horisonten. På den baggrund er det ikke overraskende, at Kirchen- und Schulblatt i 1848, da det kom til strid om kirkebønnen, kunne skrive: "Man spurgte ikke, om en gejstlig prædikede Kristus, den korsfæstede. Man spurgte kun om tysk eller dansk. Det var, jo længere mod nord desto mere, hovedsagen. ${ }^{46}$

\section{Tiden 1864-1920}

Det danske nederlag i krigen 1864 fik naturligvis følger for kirken. I 1864 blev den danskfødte Ulrik Sechmann Boesen afløst som biskop over Slesvig af slesvigeren Bertel Petersen Godt, og kirken indrettede sig efter de nye magtforhold. Kort efter sin indsættelse forordnede biskop Godt afholdelse af en "fredsfest « i alle kirker. Her lød budskabet: "Den for vort lands ret førte krig er lykkelig endt; vi må yde vort hjertes varmeste tak til den tapre preussiske og østerrigske armé og til de ophøjede monarker; men især må enhver from sjæl i landet føle dyb trang til at takke Gud. " I 1870 skulle præsterne i alle kirker bede for de tyske våbens sejr. I 1872 udtalte pastor E.W. Gardthausen i Ulkebøl ved afsløringen af det preussiske sejrsmonument på Dybbøl: "Dybbøl er den sten, Gud havde udskåret til grundsten for det tyske rige «. ${ }^{47}$ På den måde fandt den officielle kirke nu sin plads som den preussiske stats loyale støtte, ganske som den tidligere havde været den danske stats støtte.

Efter indlemmelsen i Preussen skulle kirken finde sig til rette over for nye statslige myndigheder. En direkte indlemmelse i den preussiske kirke blev der ikke tale om. I Preussen var der i 1817 gennemført en 


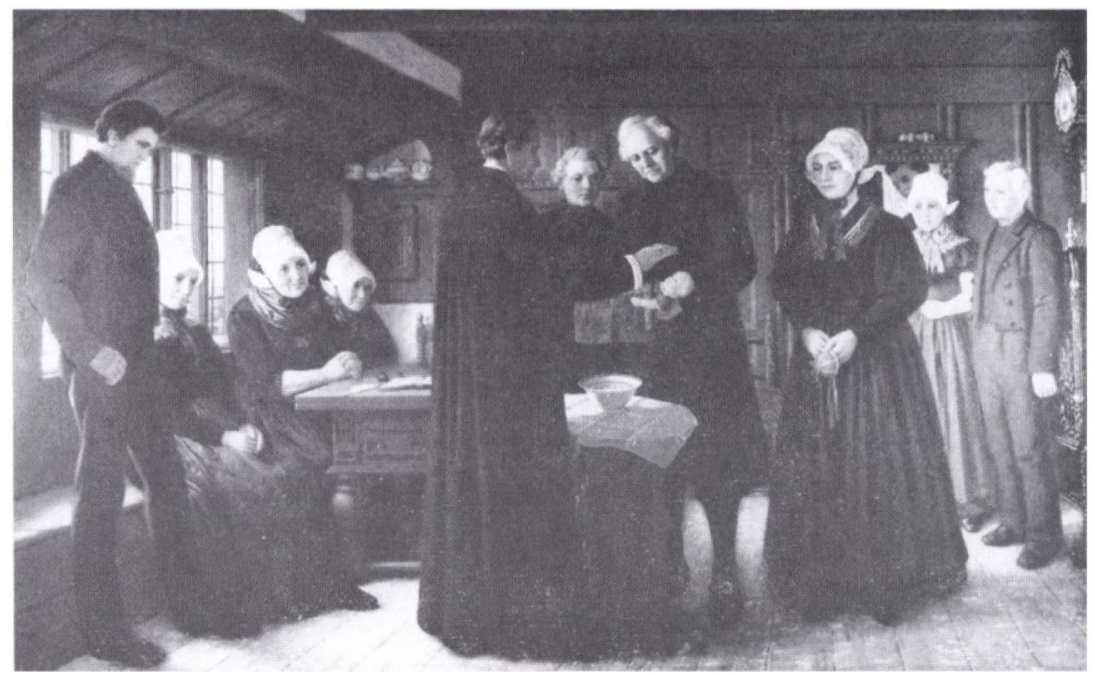

Forskelle i forvaltning, sprog og påvirkninger fra henholdsvis nord og syd medforte, at der blev forskelle $i$ kirkelige traditioner nord og syd for Kongeåen. Det gjaldt også kirkens dabshandlinger. I Slesvig blev hjemmedaib mere udbredt end nord for Kongeden. De danske præster, som kom til Nordslesvig efter 1920, og til Sydslesvig efter 1945, så det derfor som en opgave at flytte dåben, sá den igen kom indenfor menighedens og kirkens rammer. På maleriet Die Taufe fra 1903 har maleren Carl Ludwig Jessen fastholdt en hjemmedåb $i$ Vestslesvig. Gengivet efter Ernst Schlee/S. Schoubye: Carl Ludwig Jessen. Sønderjyllands Kunstmuseum, Tønder 1976.

union mellem den lutherske og den reformerte kirke. En sådan union kunne ikke accepteres i Slesvig-Holsten. Her forblev kirken rent luthersk, og den blev ikke forenet med Preussens kirke. I stedet blev den lagt direkte under kultusministeriet i Berlin, med konsistoriet i Kiel som mellemled til myndighederne i Berlin. Den preussiske konge indtrådte i den danske konges sted som kirkens overhoved, summus episcopus. For at betone forskellen til Preussen, hvor der var gennemført en forening af den lutherske og den reformerte kirke, blev det nu fremhævet, at landskirken i Slesvig-Holsten var evangelisk luthersk -i dansk tid var det en selvfølge, at kirken var luthersk. Nu blev det fremhævet som et banner, som et værn mod den unerede kirke i Preussen.

I de følgende år gennemgik kirken en betydelig administrativ modernisering og demokratisering. I 1876 gennemførtes en ny kirke- og synodalordning med et selvstyre, som var mere vidtgående end $i$ Danmark. I hvert sogn blev oprettet et valgt kirkekollegium og et kirkeforstanderskab, og for hvert provsti blev valgt en provstisynode, 
som skulle føre tilsyn med de kirkelige og sædelige tilstande i provstiet, og som kunne indsende andragender til konsistoriet og fællessynoden for hele Slesvig-Holsten. Fællessynoden førte det overordnede tilsyn, behandlede indkomne forslag og medvirkede til kirkelig lovgivning. Lovskraft fik forslagene først efter stadfæstelse af kirkeregeringen. Kirken fik således et vist selvstyre, omend staten havde gode muligheder for at sætte sine politiske krav igennem over for kirken, også i nationale sammenhænge. ${ }^{48}$

I danske fremstillinger er landskirken i preussisk tid ofte skildret som rent tysk. Det er imidlertid en noget ensidig betragtning af en meget kompliceret virkelighed. En af de afgørende kirkemænd i tiden under fremmedherredømmet var biskop Theodor Kaftan. Han var født i Løjt og virkede først som diakon i Aabenraa fra 1873 til 1880. Her havde han de danske gudstjenester som embedsopgave. Fra 1884 var han provst i Tønder, indtil han 1886 blev udnævnt til biskop. I dette vigtige embede sad han helt frem til 1917. For Kaftan var den rene lutherdom det overordnede mål. Al moderne liberal teologi var ham imod; kirkens opgave var rent religiøs, og kirken skulle $i$ alle forhold, også i det nationale, være neutral. En væsensforskel mellem dansk og tysk kristendom så han ikke. Han så landskirken som det eneste bånd, som endnu forbandt danske med tyske. ${ }^{49}$

Heri havde han ikke så lidt ret, for kirken blev det eneste offentlige forum, hvor det danske sprog fik lov at lyde nogenlunde uindskrænket i den nordlige del af Slesvig gennem alle fremmedherredømmets år. Kirken blev den eneste institution, der regnede med modersmålets ret. Ganske vist blev tysk straks i 1864 indført som kirkesprog i Sydslesvig. Sprogreskripterne, som i 1850'erne havde indført dansk skolesprog og blandet dansk-tysk kirkesprog i en række sogne i Mellemslesvig, blev nu ophævet og tysk indført næsten overalt. I Nordslesvig fik dansk derimod lov til fortsat at lyde i de fleste kirker. I 1864 forekom danske gudstjenester i 121 sogne. I 1914 var der 114 sogne med danske gudstjenester. Samtidig gik antallet af danske gudstjenester dog tilbage - med tiden indførtes stadig flere tyske gudstjenester $\mathbf{i}$ de enkelte sogne. I 1864 havde der været 102 sogne med rent dansk kirkesprog, i 1890 var der 69 sogne rent dansk kirkesprog, og i 1912 havde kun 26 sogne rent dansk kirkesprog. ${ }^{50}$ I sogn efter sogn var der med andre ord indført få eller mange tyske gudstjenester.

Kirkeledelsen havde også øje for, at det danske folkesprog og de danske gudstjenester krævede særlig uddannelse af præsterne til 
dansksprogede sogne. Præster til embeder i Nordslesvig skulle gennemgå præsteseminariet i Haderslev, oprettet 1870. Her fik kandidaterne bopæl i dansktalende familier, og de blev sendt en måned til København for at se på det kirkelige arbejde dér. ${ }^{51}$ Det styrkede deres forudsætninger for at virke i dansktalende sogne.

Også under fremmedherredømmet var de fleste præster i Nordslesvig i øvrigt født i landsdelen, omend de var tysksindede. Af 294 præster i Nordslesvig 1864-1920 var 172 født og opvokset i Nordslesvig, 21 stammede fra kongeriget. ${ }^{52}$ Landskirkens ideal var helsognspræsten, som kunne betjene både danske og tyske. Landskirken så det som sin opgave at forene danske og tyske $i$ et område, hvor alle ville være lutheranere. For de fleste af præsterne stod det også klart, at det gjaldt om at holde den nationale strid ude af kirken. I 1909 oprettedes Der nordschleswigsche Pastorenverein. Her protesteredes mod al sammenblanding af forkyndelse og national kamp. Foreningen fik snart 57 medlemmer eller halvdelen af præsterne i Nordslesvig. ${ }^{53}$

Den danske salmesang blev ikke glemt. I 1890 udkom Evangeliskluthersk Salmebog for de dansktalende Menigheder $i$ Slesvig. Bag denne fremragende salmebog stod en kommission ledet af biskopperne, først Berthel Petersen Godt og så Theodor Kaftan. Men motoren bag arbejdet var lensgreve Hans Schack på Schackenborg. Af salmebogens 624 salmer var 300 fra de gamle sønderjyske salmebøger, Grundtvigs salmer kom med i pænt udvalg. Salmebogen slog snart igennem overalt, trods nogen skepsis hos tyske præster, ikke mindst over for Grundtvigs salmer. "Der er so mange Fughle und so mange Blomster i den Salmebog « lød det - på grund af blomsterne hos Brorson og fuglene hos Grundtvig. De grundtvigske frimenigheder udarbejdede et tillæg, der udkom 1890 under navn af Salmebog for Kirke og Hjem. ${ }^{54}$

Dansk vedblev således at lyde i kirkerne i Nordslesvig, og mange udsagn viser, at befolkningen langt hen ad vejen var tilfredse med forholdene. Det fremhæves, at præsterne optrådte med en særlig værdighed, deres prædikener var ofte præget af et gammeldags bibeldansk fremført med tyskpræget retorik og med megen salvelse. For befolkningen $\mathrm{i}$ almindelighed blev dette forstået som udtryk for den rette "hellighed «. ${ }^{55}$ Samtidig fik kirken sine særlige traditioner. Hjemmedåben dominerede, og liturgien fik en særlig rig udformning $i$ disse år. I mange sogne rådede et tillidsfuldt forhold mellem menighed og præst. Vel var præsterne som oftest tyske af uddannelse og sindelag, men det hindrede ikke, at de samtidig kunne udvise respekt 
over for deres sognebørns danskhed. ${ }^{56}$ Alt $i$ alt fik landskirken i disse år et særpræg, som trods det danske sprog i hovedparten af Nordslesvigs kirker klart adskilte den fra kirken nord for Kongeåen.

Kirken syd for Kongeåen var sin egen, bygget på tradition og den egenartede sprogligt-nationale situation. Op mod dette egenliv trådte imidlertid to anderledes strømme. Begge kom nordfra. Den ene strøm forløb uden for statskirkens rammer. Det var den grundtvigske bevægelse, som fandt udtryk i de danske frimenigheder. Utilfredshed med de stadig flere tyske gudstjenester, med præsternes tyske sindelag og et andet kirkesyn præget af Grundtvig, forte mindre kredse af sønderjyder bort fra landskirken. ${ }^{57}$

Det begyndte i Rodding. Her havde sognepræsten H. Sveistrup siden 1861 været en fremtrædende talsmand for Grundtvigs menighedssyn. Det førte til hans afsættelse i 1867. Men han fortsatte med at afholde gudstjenester $\mathrm{i}$ højskolens sal, indtil han 1870 flyttede til Vejen. I Rødding blev arbejdet derefter ført videre af læreren Cornelius Appel med møder i Svejstrups ånd og med talere nordfra, indtil der i 1874 kom forbud mod at udenlandske præster holdt møder. Det blev anledning til oprettelse af Rodding Frimenighed 1874 med Cornelius Appel som præst.

Eksemplet blev fulgt i Bovlund med en frimenighed 1879, i Haderslev tilsvarende i 1894, og derefter kom menigheder i Sundeved, Skærbæk, Visby og Aabenraa. I 1914 var der i alt 9 frimenigheder med 6 præster og et samlet medlemstal på ca. 2.000 .

Alle disse grundtvigske frimenigheder måtte leve $i$ et udpræget konfliktforhold til de tyske myndigheder. De kunne ikke få anerkendelse som kirkelige institutioner - nej, de blev betragtet som rent politiske påfund. På tysk side var der ingen forståelse for, at de danske ønskede deres egen præst - landskirkens præst prædikede jo på dansk. Der var heller ikke forståelse for et grundtvigsk inspireret ønske om frit at kunne vælge egen præst. Efter tysk orden herskede jo den opfattelse, at det enkelte menighedsmedlem var bundet til sit sogn og dets præst. En grundtvigsk præget frihed i præstevalg var uforenelig med landskirkens orden.

Det førte til en lang række chikaneprægede forholdsregler over for frimenighederne og deres medlemmer. Frimenighedspræsterne blev omtalt som "Sprecher", talere, ikke præster. Bygningerne måtte ikke kaldes kirker. Når et medlem af en sognemenighed $i$ landskirken ville slutte sig til en frimenighed, betragtede landskirken det som udmel- 
delse af »kirken«, det kirkelige fællesskab som sådan, ikke blot af kirken som statsinstitution. De udmeldte blev nærmest betragtet som ikke-kristne. Det blev derfor forbudt landskirkepræster at begrave folk fra frimenighederne, klokkeringning blev forbudt ved frimenighedsmedlemmers begravelse, og i 1895 fastsatte et kirkegårdsreskript fra konsistoriet, at "talere " fra de grundtvigske frimenigheder ikke måtte fungere på kirkegårde. Enhver ceremoni for udtrådte af landskirken blev forbudt på landskirkens kirkegårde.

Den anden strøm var Indre Mission, som i højere grad fandt sit løb inden for landskirkens rammer. ${ }^{58}$ Kristelig Forening for Indre Mission i Nordslesvig blev stiftet i 1886, og var en omplantning af dansk Indre Mission til området syd for Kongeåen. Bevægelsen havde kun succes i Nordslesvig, hvor den hvervede for arbejdet med hedningemission, børneforsorg, diakoni og udgav bladet Sædekornet i et oplag, som i 1887 nåede 8000 eksemplarer. ${ }^{59}$ Bevægelsen havde til formål at arbejde for både danske og tyske uden forskel. Derfor måtte indremissionærerne ikke give udtryk for deres nationale synspunkter. Guds Riges Fremme var det eneste formål. Denne neutralitet viste sig dog umulig at overholde. Især ungdomsarbejdet efter dansk mønster (KFUM og K) med J.M. Kylling som sekretær fra 1908 fik en tydelig dansk karakter. Dette førte derfor også til splittelse. Resultatet blev 1912 splittelsen mellem "Det Gamle Budskabs Indre Mission", som udgav bladet Det gamle Budskab, og som søgte at lægge størst mulig afstand til det nationale - og Indre Mission, hvor der var større forståelse for verdens virkelighed, når det gjaldt den nationalpolitiske modsætning.

Alt $i$ alt kan konkluderes, at den nationale modsætning gav øget interesse for det kirkelige liv. I årene fra 1898 til 1918 lå nadverbesøget i Nordslesvig set i procent af landskirkens medlemstal næsten dobbelt så højt som i Sydslesvig (1898: 63\% og 29\%; 1918: 35\% og 22\%). Tilsvarende var valgdeltagelsen ved kirkelige valg i Nordslesvig mindst det dobbelte af deltagelsen i Sydslesvig (f.eks. 1898:13 og 8\% af kirkeligt stemmeberettigede). ${ }^{60}$ Heraf kan sikkert ikke udlæses en større kirkelighed i Nordslesvig. Snarere var der tale om en vis politisering af det kirkelige liv.

\section{Genforeningskirken 1920}

Ved genforeningen i 1920 stod en selvgroet landskirke syd for Kongeåen over for den danske folkekirke. Tilpasningen af kirkelivet i Søn- 


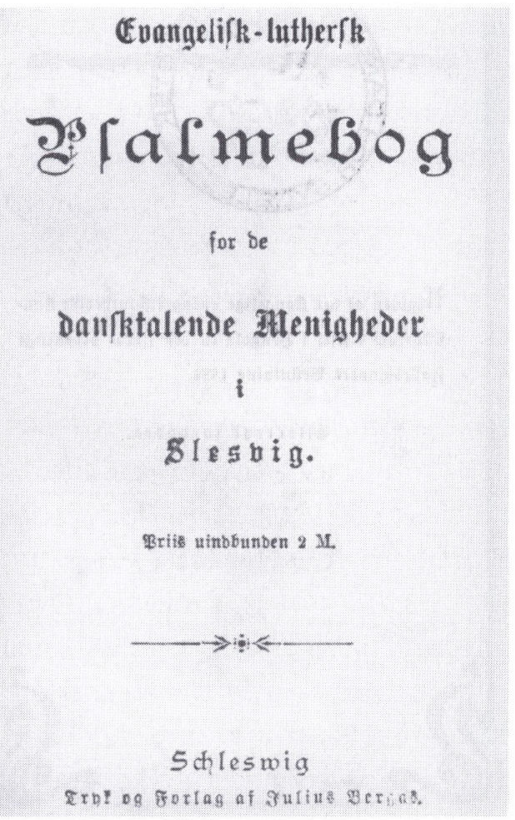

\section{DEN \\ SØNDERJYDSKE \\ SALMEBOG}

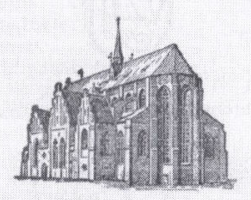

KØBENHAVN

DET KGL. VAISENHUS' FORLAG I KOMMISSION HOS P. HAASE \& SON

1926

Helt frem til 1953 var der forskelle på salmebøgerne $i$ Danmark og $i$ Sønderjylland. Evangelisk-luthersk Psalmebog for de dansktalende Menigheder i Slesvig fra 1890 betød et vældigt fremskridt for den danske salmesang. Salmebogen slog lidt efter lidt igennem $i$ hele Nordslesvig, og den fik lov at leve en tid efter genforeningen. I 1926 dannede den udgangspunkt for en midlertidig salmebog for den genvundne landsdel. Efter biskop Ammundsens forslag fik den nye salmebog titlen Den sønderjydske Salmebog. Denne blev i 1953 afløst af Den danske salmebog. Først da blev der skabt ensartede salmebogsforhold $i$ den danske folkekirke nord og syd for Kongeån. Fotos: Dansk Centralbibliotek for Sydslesvig.

derjylland efter kongerigske traditioner var en opgave, som krævede megen indføling og forståelse. Til alt held fik Sønderjylland med biskop Valdemar Ammundsen den helt rigtige mand til at formidle dette kunststykke. ${ }^{61}$ Som biskop over Haderslev Stift 1923-36 stod det klart for Ammundsen, at kirkeskikkene fra kongeriget ikke straks kunne erstatte det hævdvundne i Sønderjylland. Dansk kirkedåb kunne ikke straks afløse slesvigsk hjemmedåb, den rige slesvigske liturgi kunne ikke straks sættes til side for den mere puritanske danske liturgi, den danske salmebog gjorde ikke den nordslesvigske overflødig. For Ammundsen var tilmed den sønderjyske helsognspræst, præsten for begge nationale parter, det ideal, som tiden krævede. 
Præstevalgene i 1920 bekræftede dette. Der var dengang i alt 106 præster i Nordslesvig. Heraf kom 46 præster på valg, og 39 blev genvalgt af menighederne. I alt 47 sognepræster fortsatte i Nordslesvig fra den tyske tid og ind i den danske. ${ }^{62}$ Sønderjylland blev derfor ikke delt mellem en dansk og en tysk kirke, og linjen fra tiden forud blev ikke brat afbrudt. Det mest radikale brud var vel den nye stiftsinddeling, hvor Sønderjylland blev delt på langs, så den vestlige del gik til Ribe, og Østsønderjylland sammen med området op til syd for Horsens blev et nyt Haderslev stift. Derved undgik man at danne en særlig sønderjysk kirke.

Valdemar Ammundsen var selv den allermest kyndige iagttager af udviklingen i disse år. I Sønderiyllands Historie V fra 1933 skrev han en fremstilling af kirkehistorien i perioden 1864-1920, som endnu den dag i dag er særdeles læseværdig. Han var ikke i tvivl om, hvad der burde være kirkens mål. Det måtte være at samle danske og tyske om evangeliet, ikke splitte mellem dansk og tysk. Men han måtte erkende, at det ikke altid lykkedes. Ammundsens dom om tiden under fremmedherredømmet var dristig, set fra en dansk vinkel. Det danske kirketilbud, de danske frimenigheder, skrev han, havde ikke kunnet forene danske og tyske $i$ en fælles kirke. Og han fortsatte: "Var dette dog ikke det højeste mål, i en væsentlig ensartet befolkning, hvor alle ville være lutheranere? Æren og vanskeligheden ved denne omfattende tjeneste tilfaldt alene landskirken. «" ${ }^{63}$ Sådan skrev den danske genforeningsbiskop om den officielle tyske kirke under fremmedherredømmet. Den kirke, som af mange danske almindeligvis blev beskrevet som ensidig tysk.

\section{Dansk kirke contra tysk kirke - lutherske kirker i konflikt}

Ammundsen ønskede forsoning - at evangeliet skulle være hævet over den nationale strid. Sådan gik det nu ikke. 1900-årene oplevede snarere en kulmination af modsætningen dansk-tysk i kirken. Modsætningerne var kommet klart frem under fremmedherredømmet. Der var bl.a. tale om en modsætning mellem på den ene side et dansk, friere kirkesyn, praktiseret af især de grundtvigske frimenigheder, og på den anden side et tysk kirkesyn, repræsenteret af landskirken, præget af et mere stift og formalistisk system. Dette parret med den konfliktfyldte politiske udvikling i grænselandet frem til midten af 
1950'erne medførte, at modsætningen dansk-tysk kastede lange skygger ind over kirkerne og længe hindrede et harmonisk samspil mellem kirker, som $i$ øvrigt havde samme bekendelse.

Modsætningen og dens sene afslutning træder mest klart frem, når man ser på udviklingen i Sydslesvig. Her havde Flensborg gennem alle år siden 1864 bevaret en særstilling. ${ }^{64}$ Lige frem til 1920 blev danske gudstjenester bibeholdt i Helligåndskirken. De blev udført af én af landskirkens præster. Under de friere forhold efter 1920 var dette imidlertid ikke nok for medlemmerne af den danske kreds. Den kirkelige Flensborg-forening Kirkeligt Samfund ønskede nu efter 1920, ligesom frimenighedsfolkene i Nordslesvig havde gjort det under fremmedherredømmet, at den dansktalende landskirkepræst blev afløst af en præst, der ikke blot talte, men følte dansk. Man krævede »en præst som havde forståelse for os også i national henseende«, det vil sige en kongerigsk præst med tilstrækkelig forståelse for dansk menighedsliv. Dog ønskede man, at en sådan præst skulle virke inden for landskirken - ikke som frikirkepræst. Kun hvis kravet ikke blev imødekommet af landskirken, ville man i nødsfald oprette en frimenighed.

For landskirken og den hidtidige danske landskirkepræst ved Helligåndskirken, Thomas Matthiesen, forekom det dog ganske uberettiget at omplante rigsdanske skikke til Flensborg. Det ville være brud med traditionen, så meget mere som danske ifølge den allerede bestående ordning kunne betjenes inden for landskirkens rammer og i det danske sprog. Landskirken erklærede sig også villig til at tillade flere danske gudstjenester inden for landskirkens rammer eventuelt med en fra Nordslesvig tilflyttet præst. En kongerigsk præst kunne derimod ikke accepteres. En eventuel dansk frimenighed ville blive betragtet som politisk forening. ${ }^{65}$

Denne uenighed endte $\mathrm{i}$ hårdknude. Da parterne ikke kunne finde hinanden, blev resultatet, at der blev oprettet en dansk frimenighed uden for landskirken: Den danske Menighed i Flensborg, stiftet den 13. maj 1921. Det skete i tilknytning til Dansk Kirke i Udlandet. Herudaf er i dag vokset Dansk Kirke i Sydslesvig.

Samlivet mellem denne danske nydannelse og den tyske landskirke blev i de følgende år præget af skarp konfrontation. Årsagen lå i et sammenstød mellem dansk og tysk kirkesyn. Landskirken åbnede ikke mulighed for praktisering af de kirkelige frihedsrettigheder, som var en selvfølge i det grundtvigsk prægede Danmark. Set med lands- 

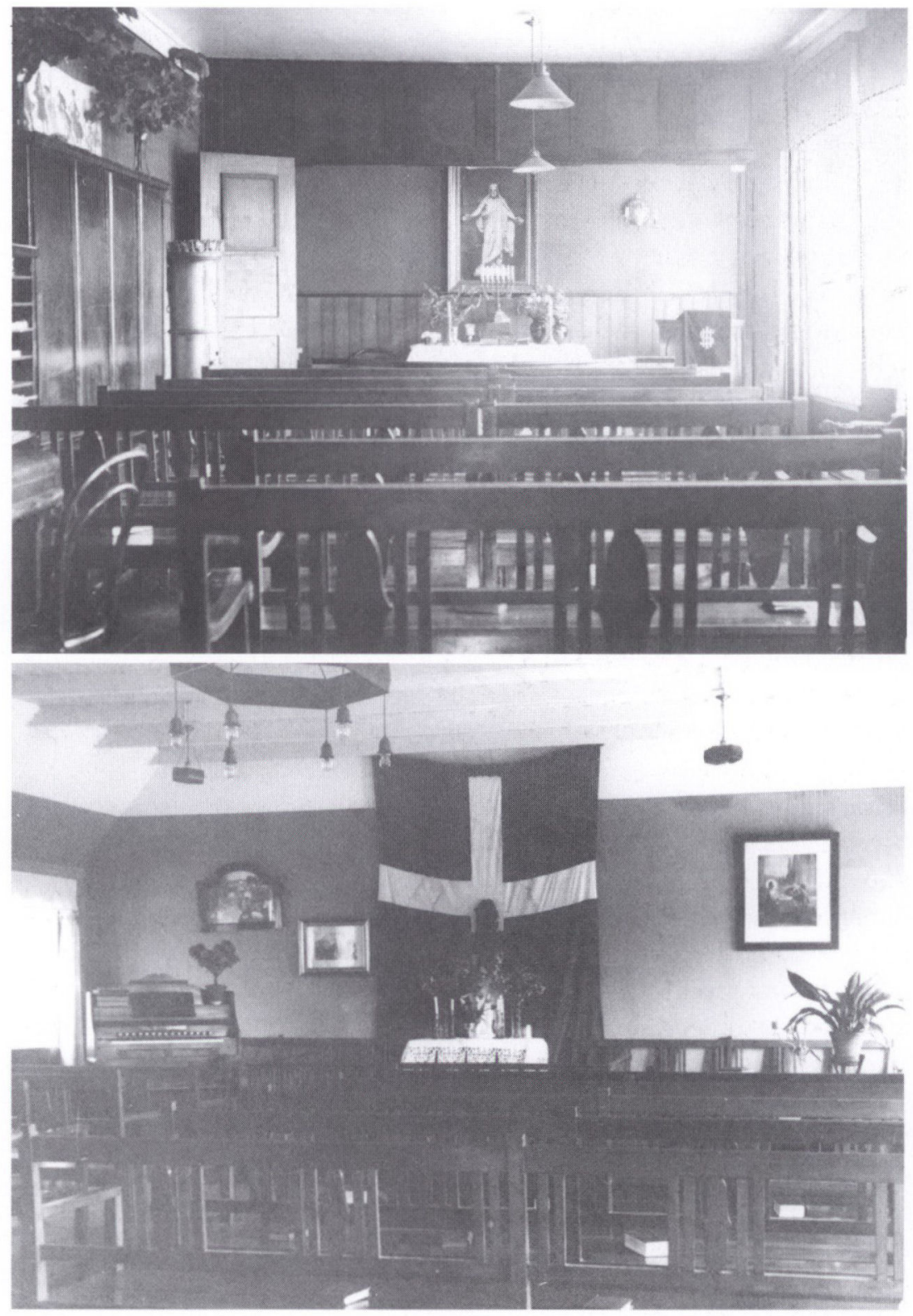

I dansk kirkearbejde i Sydslesvig efter 1920 kunne man mode flere forskellige holdninger til det nationale. Menigheden $i$ Flensborg levede under mottoet "Eet er fornodent" og søgte at holde sig sả neutralt som muligt. I Valsbol derimod blev der praktiseret et kirkeliv af udpræget grundtvigsk-dansk karakter. Forskellen kan aflæses af inventaret $i$ menighedernes kirkerum. For oven ses kirkesalen $i$ Harreslev forsamlingshus 1930. Alteret præges af Kristusfiguren. For neden kirkesalen $i$ Lorens Jepsens gård $i$ Valsbol. Her er en lille udgave of Thorvaldsens Kristusfigur på alteret overtonet af Dannebrog på væggen bagued. Fotos: Arkivet ved Dansk Centralbibliotek for Sydslesvig. 
kirkens øjne måtte en dansktalende landskirkepræst fuldt ud kunne tilfredsstille de danske ønsker. Begge kirker havde jo samme bekendelse, og hvis landskirkepræsten prædikede på dansk, måtte det være nok. Krav om en kongerigsk præst, der var fortrolig med kongerigske skikke, kunne derfor kun skyldes politiske motiver. Tysk lovgivning indeholdt tilmed ikke regler, som muliggjorde en særmenighed inden for landskirken. For landskirken var sognebåndet en selvfølge. Det enkelte menighedsmedlem var bundet til sin sognepræst - afvigelse krævede særlig tilladelse. Sognepræsten kunne tillade, at en "fremmed « landskirkepræst udførte embedshandlinger for ikke-sognebørn. Men den fremmede præst skulle i så fald melde tilbage til sognepræsten, når handlingen var udført, så handlingen kunne blive indført i sognets kirkebøger. Sognepræsten var ansvarlig for kirketugten - at menighedsmedlemmers børn blev døbt, at vielser kun blev foretaget for døbte og konfirmerede. Alt dette forudsatte en samlet kirkebogsføring. Det var ikke muligt at tillade en fremmed præst at udføre embedshandlinger for landskirkemedlemmer. Det var at "underminere vort fædreland og vor kirke«, som provst Sommer i Slesvig skrev 1923. Konsistoriet var modstander af, at danske præster fik tilladelse til kirkelige handlinger - det kunne mistolkes som om de havde ret til at betjene landskirkemedlemmer. Nok var samarbejde med præster af samme konfession ønskelig, men det var svært at nære tillid til de danske. Den danske kirke foretog "en notorisk sammenblanding af nationale og kirkelig interesser «, hed det fra landskirken i $1923 .{ }^{66}$

Hertil kom det national-politiske konfliktstof. På tysk side ville man ikke se det berettigede $i$, at danske præster nu tiltrak medlemmer af de tyske menigheder, personer som tilsyneladende før havde følt sig hjemme i landskirken, og som oven i købet kun beherskede dansk mangelfuldt. Dertil var tyskerne dengang nærmest hudløse efter nederlaget 1918 og tabet af Nordslesvig, og de led hårdt under inflationstiden. Alt dette gjorde, at det blev så svært at finde en modus vivendi mellem dansk og tysk kirkeliv i Sydslesvig. Konfliktstoffet bestod næsten uændret helt frem til 1960'erne.

I 1924 blev der erklæret boykot af det danske kirkearbejde. Det blev foreskrevet, at danske og tyske præster ikke måtte optræde sammen, embedshandlinger af danske præster skulle ikke indføres i tyske kirkebøger, landskirkens præster burde undgå at benytte dansk ved embedshandlinger, og principielt skulle kirkerne være lukket for danske præster. ${ }^{67}$ 
En vis lempelse kom i 1933 og blev udtrykt $i$ en særlig kirkelig »nødforordning $\ll$. Her hed det, at kirkeregeringen undtagelsesvist kunne ligestille præster uden for landskirken med landskirkens egne præster. Derved var åbnet mulighed for, at danske præster kunne få lov at udføre kirkelige handlinger overfor landskirkemedlemmer samt få adgang til at benytte kirkebygningerne. En sådan ret blev i 1933 givet den danske præst H.F. Petersen fra menigheden i Flensborg. Betingelsen var, at den danske præst skulle holde sig udelukkende til dansk. Han skulle ikke have lov til bruge tysk og derved at "hverve" blandt tysktalende. Ved embedshandlinger skulle han indhente »afmelding « hos sognepræsten, og der skulle meldes tilbage af hensyn til indførelse i kirkebogen. ${ }^{68}$

\section{Efter 1945 - konfrontation og nyt møde}

Med disse indrømmelser fra landskirkens side overlevede det danske kirkearbejde i Sydslesvig naziårenes periode. I 1945 kom det store nybrud. Pludselig dukkede der over hele Sydslesvig onsker frem om danske gudstjenester og danske præster. Kilderne fortæller om forbløffende deltagertal til danske gudstjenester - også på steder, hvor der hidtil ikke var holdt danske gudstjenester overhovedet.

Den 5. august 1945 deltog f.eks. 100 i dansk gudstjeneste i Sønder Brarup. Den 19. august 1945 var der 120 i Arnæs. Den 26. november 194580 i Aventoft, den 20. januar 1946250 i Sønder Brarup, den 28. april 1946250 i Rendsborg, og den 12. december 194680 i Arnæs. Forældre strømmede til kirke og lod deres allerede store børn døbe. Egtefolk, som kun var blevet borgerligt viet på det kommunale personregister, Standesamt, søgte den kirkelige velsignelse hos den danske præst. Kun sjældent beherskede de nye kirkegængere i den danske kirke det danske sprog.

Dansk Kirke i Udlandet tog de pludselige kirkeønsker fra Sydslesvig alvorligt. Den 30. januar 1946 blev onskerne udtrykt således fra Sydangel: »Angelboerne er meget religiøse og ivrige kirkegængere, og den danske kirkes hjertevarme, som ikke findes i den tyske kirke, har bevirket en stadig stigende tilgang til de danske menigheder. [...] Deltagerne forstår dansk og bliver ejendommelig berørt, når en dansk præst taler netop på grund af den hjertevarme, som den tyske kirkes præster ikke giver udtryk for. ${ }^{69}$

Udtalelserne overbeviste ledelsen i Dansk Kirke i Udlandet om, at 


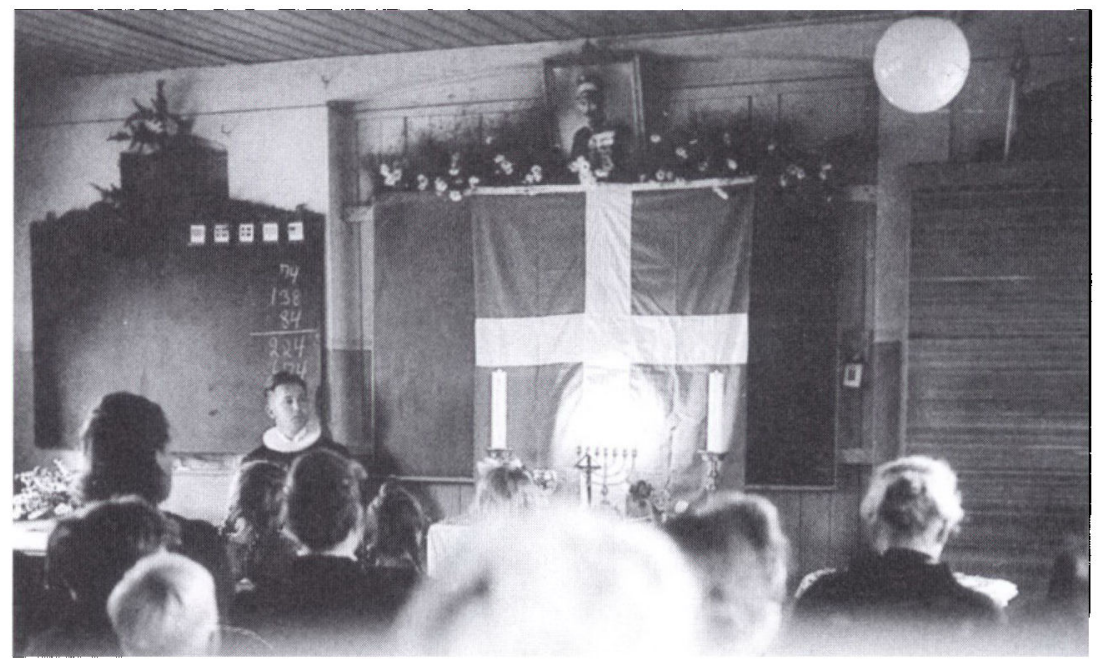

Efter 1945 gennemgik dansk kirkelivi Sydslesvig en vældig udvikling. Opbygningen af nye danske menigheder foregik som led $i$ tidens nationale arbejde. Kirkelige og nationale symboler optrådte $i$ nær alliance. Det kommer tydeligt til udtryk på dette billede fra en gudstjeneste $i$ Maarkær skole $i$ 1948. Dannebrog er altertavle, over alteret hænger kong Christian X's portræt. Foto: Arkivet ved Dansk Centralbibliotek for Sydslesvig.

bevægelsen var ægte. Mange kirkeligt orienterede folk følte, at det nu måtte være det kristne Danmarks opgave at bringe den frelsende tro tilbage til Sydslesvig. Det afkristnede Sydslesvig skulle genvindes for troen. Derfor besluttede Dansk Kirke i Udlandet at udbygge sit arbejde i Sydslesvig. Når der blev ytret ønsker fra Sydslesvig om danske præster, skulle svaret fra Danmark være positivt.

Bag engagementet lå en grundtvigsk inspireret holdning, som vi mødte den ovenfor: „Det menneskelige er jordbunden, hvori det evige liv må plantes ind ovenfra gennem evangeliet, men hvoraf planten atter tager sin form, derfor må kræves en dansk kristendom. Den kristendom Jesus skaber er forskellig efter den folkeejendommelighed, der foreligger. ${ }^{70}$ Sydslesvig og sydslesvigerne blev opfattet som danske. Derfor måtte de have en dansk kristendom.

Resultatet var forbløffende. I løbet af kort tid skiftede den danske kirke i Sydslesvig helt udseende. I 1944 havde der været tre danske præster. I maj 1946 var tallet 11, og ved udgangen af 1946 havde Dansk Kirke i Udlandet accepteret 20 præstestillinger. I 1956 var der 24 danske præster, som holdt gudstjeneste omkring 100 steder. I 1969 
fandtes 56 menigheder med tilsammen 6.000 medlemmer. I dag har Dansk Kirke i Sydslesvig 24 præster i 39 menigheder med omkring 6.600 medlemmer.

Udbredelsen af den danske kirke foregik således som en integreret del af den politisk-nationale nyorientering. Bag den danske kirke lå Grundtvigs syn: Til dansk folkelighed hører en særlig dansk kirke. Befolkningens ønsker og handlinger efter 1945 blev tolket derhen, at Sydslesvig oplevede en genfødelse af sin oprindelige danskhed. $\mathrm{Og}$ eftersom kirken efter dansk opfattelse er en uadskillelig del af dansk "folkelighed ", måtte en dansk kirke bringes til Sydslesvig.

Netop denne holdning gør det muligt at forstå den slesvig-holstenske landskirkes reaktion. Den levede stadig med den stive kirkeforfatning fra 1922. Den gav ikke plads til dansk kirkefrihed. Det gjorde en konflikt uundgåelig. Ifølge opfattelsen i landskirkens ledelse var sydslesvigerne tyske: De talte tysk. Desuden repræsenterede landskirken og den danske kirke samme trosbekendelse. De ønsker om et dansk kirkeliv, som blev fremsat af hidtil tyske sydslesvigere, kunne derfor kun være uægte: »Med missionærisk iver strømmer de danske præster og lærere over grænsen og indretter den ene danske gudstjeneste og den ene danske skole efter den anden - på tysk, da jo næppe nogen forstår dansk - og mener, at de udstrøer evangeliets sæd på en tjenlig jord, som vil bringe god frugt; hvilken frugt? At landet bliver dansk! Det, der foregår her, er den sammenblanding af nationalisme og evangelium, " udtalte præses for landskirkens kirkeledelse, Wilhelm Halfmann, i juli 1946. Landskirken kunne ikke acceptere en fri afgørelse af den enkelte. "Hvis Gud har skabt os som tyske, så er vor skæbne dermed fastlagt«, erklærede fællessynoden i september 1946. ${ }^{71}$ Landskirken havde oplevet en tysk kristendom under nazitiden. $\mathrm{Nu}$ gjaldt det for kirken om at holde sig fri af det nationales faldgrube - hævdede man fra tysk side.

Af disse grunde blev "nydanskernes « kirkeønsker afvist som politiske og ikke-kirkelige. F.eks. afviste kirkebestyrelsen for Christkirche i Rendsborg den 21. juni 1946 med følgende begrundelse et andragende fra Sydslesvigsk Forening om overladelse af kirken til danske gudstjenester: »1) fordi dette andragende ikke er fremsat af en kirkelig organisation eller forening, men af en politisk forening; 2) fordi den planlagte foranstaltning trods det kirkelige anstrøg tjener politisk propaganda; 3 ) fordi der ikke foreligger behov for en dansk gudstjeneste i Rendsborg, da medlemmerne af Sydslesvigsk Forening besid- 
der tilstrækkeligt tysk sprogkendskab til at deltage i tysk gudstjeneste. $\kappa^{72}$

Med disse udtalelser viste landskirken, at også dens holdning entydigt blev præget af nationalpolitiske overvejelser. F.eks. udtalte den tidligere biskop i landskirken Eduard Völkel i 1946, at landskirken i den foreliggende situation skulle vise sig som en tysk kirke i kamp for folk og fædreland: Til en protestantisk kirke hørte en stærk binding til sit eget folk. "En tysk kirke, som uden kamp overlader tyske medlemmer til danskerne, forbryder sig mod alle ti bud, begyndende med det første bud «, advarede han. ${ }^{73}$

Kort sagt: Begge lutherske kirker var spundet ind i det nationale. På dansk side foregik et kirkearbejde udsprunget af en politisk bevægelse og som en naturlig følge af den sammenhæng mellem kirke og folk, som præger dansk opfattelse. På tysk side var der ikke forståelse for de danske ønsker om fri udfoldelse. Det danske kirkearbejde blev tolket udelukkende som nationalt inspireret og som en trussel. Derfor blev kirkerne i disse år mere front end bro. Bro kunne de først for alvor blive, da det nationale grænseproblem blev løst fra midten af 1950'ere. Hovedtrinnene på den vej var følgende: ${ }^{74}$

1947: danske præster i Sydslesvig blev ligestillet med landskirkens præster, men det måtte ske inden for rammerne af den tyske kirkelov. De danske præster blev forpligtet til udelukkende at bruge dansk $\mathbf{i}$ kirkerne, og de skulle overholde landskirkens ordninger, når de foretog embedshandlinger for medlemmer af landskirken. De måtte respektere det tyske begreb »kirketugt«.

1948: den danske kirke foreslår at danne en valgmenighed indenfor landskirken. Det blev afvist fra tysk side, fordi lovgivningen ikke gav mulighed for en sådan ordning.

1950: landskirken anbefaler som modforslag den danske kirke at danne en frimenighed uden for landskirken. Men det kunne danskerne ikke gå med til, da medlemmerne ikke var villige til at træde ud af landskirken. Den danske kirke var endnu ikke moden til en sådan selvstændighed. Derefter blev ligestillingen af de danske præster trukket tilbage.

1955: landskirken udsteder en lov om brug af dansk ved gudstjenester og embedshandlinger. Loven var tænkt som en imødekommende gestus. 1955 er året for udstedelsen af Bonn-København-erklæringerne. Men den danske kirke valgte ikke at gøre brug af loven. Den kunne ikke acceptere bestemmelserne om overholdelse af landskir- 
kens orden og forbudet mod at benytte tysk. Loven gav ikke den ønskede frihed.

I de følgende år arbejdede de to kirker herefter mere eller mindre ved siden af hinanden uden officiel kontakt. Først i 1960erne var afspændingen mellem folk i almindelighed og mellem præsterne i særdeleshed nået så vidt, at forudsætningerne for en aftale var til stede. Økumeniske tanker bredte sig, grænsekampen gik ind i en ny fase. Det tyske krav om overholdelse af en bestemt kirketugt, en bestemt kirkelig orden, syntes ikke længere uomgængeligt for yngre præster. I 1968-69 fandt disse tendenser udtryk i lovgivning. Kirkeloven »Zur Regelung der Zusammenarbeit mit der dänischen Kirche in Südschleswig e.V.« af 15 . november 1968 var båret af samarbejdets ånd. Det blev en lov udstedt efter forhandling mellem begge parter - ikke et tysk diktat. Den danske kirke skulle ikke indrette sig uden for landskirken, men virke i samarbejde med den. Dens præster blev anerkendt, sognekirkerne blev stillet til dens rådighed, de danske præster blev ikke bundet til kun at anvende dansk sprog, dansk ritual kunne frit benyttes. Eneste krav var, at præsterne skulle præsenteres for biskoppen ved tiltrædelsen, og de skulle tage hensyn til landskirkens ordninger, når de udførte embedshandlinger for medlemmer af landskirken. ${ }^{75}$

Denne sidste bestemmelse var en reminiscens af gammel tysk lovgivning og fremkaldte kritik fra danske præster. De mente, at loven ofrede dansk frihed og bandt dem til landskirkens orden. Da den danske part godkendte loven, fremhævedes derfor næsten som en advarsel, at man kun ville tage hensyn til landskirkens orden, så vidt det var foreneligt med folkekirkens ordninger. Heldigvis viste det sig, at forbeholdet knap nok var berettiget. Lovens ord var nemlig ikke udtryk for et benhårdt ønske om at fastholde gamle normer. De stod der mest for at berolige kritikere på tysk side. Den tyske biskop Alfred Petersens reaktion over for de danske forbehold blev derfor meget afslappet. Han fandt det whelt $i$ orden «. Det var i sandhed en ny liberal indstilling! Dermed var anslået en tone, som beskyttede nyordningen mod skibbrud. Den kunne blive fyldt med reelt liv. Langt om længe havde de to parter accepteret hinandens eksistens front var afløst af bro.

Udviklingen siden da peger i følgende retning: På begge sider af grænsen er der fri udfoldelse for det evangelisk lutherske kirkeliv. Enhver kan frit vælge, hvor han helst vil gå hen. Det er måske endda 
i dag sådan, at den tyske kirke praktiserer den største frihed - f.eks. når det gælder hvad præster kan ytre sig om, eller hvad kirker kan bruges til. De to kirker er i dag for alvor blevet bro - fordi vi i det store og hele er kommet ud af en tid, hvor det nationale var et problem. Den ene part kan uden frygt give plads for den anden, og behøver ikke frygte for at blive løbet over ende. Kirkerne er ikke længere gidsler af det nationale - men kan samle sig om det egentlige. Kirken og kirkerne i grænselandet har virkelig tilbagelagt en lang vej, siden den lutherske kirkeordning blev indført i årene fra 1528 til 1542.

Artiklen er en omarbejdet udgave af forfatterens foredrag Sønderjylland som front og bro - lutherske kirker mellem dansk og tysk, holdt i Haderslev 12. august 2003 på konferencen »Christian III. Haderslev og reformationen 1536. Brud og kontinuitet«. Seminaret blev gennemført i samarbejde mellem Haderslev Stift og CVU Sønderjylland.

\section{NOTER}

1. Jargen Larsen: Sønderjyllands Kirkehistorie, 1946, s. 55-57.

2. Ibid. endvidere H.V. Gregersen: Af Slesvig stifts historie indtil 1850, i: Dansk præste- og sognehistorie $X$, 1977-85, s. 12-16. J. Skovgaard i Slesvigs delte bispedømme, 1949, s. 54 .

3. J. Skovgaard, 1949 s. 121.

4. Senderjyllands Historie bd. 3, $1941 \mathrm{~s}$. $220 \operatorname{og} 224$. Lars N. Henningsen: Ensted sogns historie, 1987, s. 75.

5. Lars N. Henningsen: Jubelfesterne 1749 og 1760 . Konge- og statsdyrkelse under enevælden, i: Sonderjyske årbeger 2000 s. 37.

6. J.P. Bang: Kristendom og nationalitet, 1900, s. 103.

7. Citeret efter Holger Hjelholt i Sønderjyllands historie bd. 3, s. 363.

8. Alex Wittendorf: På Guds og Herskabs nåde, Gyldendal og Politikens Danmarks historie bd. 7, 1992, s. 245.

9. H. Hejselbjerg Paulsen i: Slesvigs delte bispedomme, 1949 s. 143.

10. Slesvigs delte bispedømme, 1949 s. 66ff, 144.

11. Slesvigs delte bispedomme, 1949 s. 85-119 samt Otto Fr. Arends: Gejstligheden i Slesvig og Holsten fra reformationen til 1864, 1-3, 1932.
12. Asger Nyholm: Slesvigske gejstlige og slesvig-holstenismen, 1980 s. 66 og s. 115-123.

13. Benito Scocozza: Ved afgrundens rand. Gyldendal og Politikens Danmarkshistorie, 1992, s. 121-125. Hal Koch: Danmarks kirkehistorie gennem tiderne, 1944, s. $75 f$.

14. J. Skovgaard i Senderjyllands Historie bd. 3, s. 108-110.

15. Ibid., s. 110-118, endvidere H.F. Petersen i Sydslesvig gennem tiderne, 2, 1949 , s. $765-769$.

16. J. Skovgaard, i: Slesvigs delte bispedømme, 1949 s. 87-89.

17. C. F. Allen: Det danske Sprogs Historie i Hertugdømmet Slesvig, 1, 1857 s. 119121. J. Skovgaard, i: Sønderjyllands Historie bd. 3, s. 120 og 148.

18. J. Skovgaard, i: Slesvigs delte bispedømme, 1949 s. 94-99.

19. Ibid. s. 104-119.

20. Johannes Pedersen, i: Den danske kirkes historie bd. 5, 1951. Hal Koch: Danmarks kirkehistorie gennem tiderne, 1944 s. 84.

21. Jørgen Larsen: Senderjyllands kirkehistorie, 1946 s. 80-87.

22. H. Hejselbjerg Paulsen: Oplysningstiden i hertugdømmerne, i: Sonder- 
jydske Aarbøger 1933, 1934, 1935, 1936 og 1938.

23. Bjørn Kornerup i Den danske kirkes historie bd. 5, 1951 s. 396-409.

24. Anders Malling i Slesvigs delte bispedømme, 1949 s. 310. Jørgen Larsen: Sønderjyllands kirkehistorie, $1946 \mathrm{~s}$. 94.

25. Bjørn Kornerup i Den danske kirkes historie bd. 5, 1951 s. 409. Holger Hjelholt i Sønderjyllands historie bd. 3, s. 462-465. Jorgen Larsen: Senderjyllands kirkehistorie, 1946 s. 95.

26. H.V. Gregersen i Slesvig og Holsten for 1830,1981 s. 239 og 250 f.

27. Sønderjyllands Historie bd. 3 s. 382 . H. Hejselbjerg Paulsen, i: Slesvigs delte bispedømme, 1949 s. 226.

28. Senderjyllands Historie bd. 3 s. 310 . Günter Weitling i Sct. Nicolai kirke i Aabenraa, 2002 s. 67.

29. J.Skovgaard i Slesvigs delte bispedømme, 1949 s. 113.

30. H. Hejselbjerg Paulsen i Slesvigs delte bispedømme, 1949 s. 218f.

31. H. Hejselbjerg Paulsen i Slesvigs delte bispedømme, 1949 s. 229. H.F. Petersen i Sydslesvig gennem tiderne, 2 , 1949 s. $769 f$.

32. C.F. Allen: Det Danske Sprog i hertugdømmet Slesvig, 1, 1857 s. 189199. Jørgen Larsen: Sønderjyllands Kirkehistorie, 1946 s. 76 . Sonderjyllands Historie bd. 3 s. 383.

33. Citeret efter Troels Fink i Sydslesvig gennem tiderne, 1, 1946 s. 324.

34. Allen: Det danske sprog i Hertugdømmet Slesvig, 1, 1857, s. 283. J.Skovgaard i Slesvigs delte bispedømme, 1949, s 114-116. Sonderiyllands historie bd. 3 s. 480 . H.F. Petersen i Sydslesvig gennem tiderne, 2, 1949 s. $773 f$.

35. Senderjyllands Historie bd. 4, s. 57.

36. Ibid. s. 60 .

37. Asger Nyholm: Slesvigske gejstlige og slesvig-holstenismen indtil 1850, 1980 s. 51.

38. Asger Nyholm: Om Claus Harms og hans indflydelse på hertugdømmernes kirkeliv, i: Sønderjyske årbøger 1970 s. 1-86. Samme: Slesvigske gejstlige, 1980 s. 49.

39. Asger Nyholm: Slesvigske gejstlige, 1980 s. 54-63.
40. Citeret efter Sønderjyllands Historie bd. 4 s. 126.

41. Citeret efter Frode Beyer: Det kristelige og det nationale. I: Front og Bro, 8. årgang, 1957-58 s. 190.

42. Valdemar Ammundsen, i: Sønderjyllands Historie bd. 5 s. 336.

43. J.P. Bang: Kristendom og Nationalitet, 1900 s. 59.

44. Asger Nyholm: Slesvigske gejstlige, 1980 s. 81 .

45. Ibid. s. 61.

46. Ibid. s. 177.

47. Valdemar Ammundsen, i: Sonderjyllands Historie bd. 5 s. 319, 328 og 335.

48. Ibid. s. 358-361.

49. Valdemar Ammundsen, i: Sønderjyllands Historie bd. 5 s. 362-364. Henry Petersen i Dansk Præste- og Sognehistorie X s. 48-58.

50. Valdemar Ammundsen, i: Sonderjyllands Historie bd. 5 s. 382. H. P. Hanssen: Statskirkens Fortyskning i Nordslesvig, i: Sønderjydske Aarbøger 1897 s. 138-164. N. Hansen: Statskirkens Fortyskning i Nordslesvig, i: Sonderjydske Aarbøger 1913 s. 161252.

51. Valdemar Ammundsen i Sønderjyllands Historie bd. 5 s. $369 f$.

52. H. Hejselbjerg Paulsen i Slesvigs delte bispedømme, 1949 s. 159.

53. Hans Schultz Hansen: For kejser og rige. - Den nye hjemmetyskhed 18711914 i Lars N. Henningsen (red.): Grænselandshistorie gennem 40 år, 2003, s. 213.

54. Anders Malling i Slesvigs delte bispedømme, 1949 s. 322.

55. Valdemar Ammundsen, i: Sonderjyllands Historie bd. 5 s. 370 .

56. Thade Petersen i Franz v. Jessen: Haandbog i det slesvigske Sporgsmaals Historie 1900-1937, bd. 1, 1938 s. 76 .

57. Vald. Ammundsen i Sønderjyllands Historie bd. 5 s. 336-347.

58. Valdemar Ammundsen i Sonderjyllands Historie bd. 5 s. 391-405.

59. Thade Petersen: Kirken og menighedslivet i Franz v. Jessen: Haandbog i det slesviske Sporgsmaals Historie 1900-1937, bd. 1, 1938 s. 88.

60. Thade Petersen i Franz v. Jessen: Haandbog i det slesvigske Spørgs- 
maals Historie 1900-1937, bd. 1, 1938 s. 88.

61. Frode Beyer: Valdemar Ammundsen. Liv og virke, 1954. Urban Schrøder i Dansk Præste- og Sognehistorie $X \mathbf{s}$. 61-66.

62. Urban Schrøder i Dansk Præste- og Sognehistorie X s. 69.

63. Valdemar Ammundsen i Sonderjyllands Historie bd. 5 s. 372.

64. Johann Runge: Der lange Weg zur Gründung einer dänischen Gemeinde in Flensburg, i: Flensburg 700 Jahre Stadt, Bd. 1, 1984 s. 158-179.

65. Lars N. Henningsen: Kirke og folk i grænselandet. Dansk kirke i Sydslesvig 1921-1996, 1996 s. 17-30.

66. lbid. s. 49 .

67. Ibid. s. 51 f.
68. Ibid. s. 91.

69. Lars N. Henningsen, 1996 s. 146. Samme: Kirkeliv og identitet, Dansk Kirke i Sydslesvig 1945-2000, i: Jørgen Kühl (red.): En europæisk model? Iinstitut for Grænseregiosnforskning, Abenraa 2002, s. 265-280.

70. jvfr. ovenfor note 42. Vald Ammundsen, i: Sonderjyllands Historie bd. $5 \mathrm{~s}$. 336.

71. Lars N. Henningsen, 1996 s. $190 f$.

72. Lars N. Henningsen: Kirkeliv og identitet. Dansk Kirke i Sydslesvig 1945-2000, i: Jørgen Kühl: En europæisk Model? IFG, 2002, s. 275.

73. Kurt Jürgensen: Die Stunde der Kirche, Neumünster 1976 s. 205.

74. Lars N. Henningsen, 1996 s. 199-213.

75. Ibid. s. 252. 